\section{COVID-19 and the Unraveling of Experimental Medicine - Part I}

\author{
K. E. Thorp ${ }^{1}$, James A. Thorp ${ }^{2 \star}$, Elise M. Thorp ${ }^{3}$
}

'Department of Radiology, Sparrow Health System, Lansing, MI

${ }^{2}$ Department of Obstetrics and Gynecology, Division of Maternal Fetal Medicine, Sisters of St. Mary's Health System, St. Louis, MO.

${ }^{3}$ BS, FNTP
Address for correspondence:

James A. Thorp, Department of Obstetrics and Gynecology, Division of Maternal Fetal Medicine, Sisters of St. Mary's Health System, St. Louis, MO

How to cite this article: Thorp KE, Thorp JA, Thorp EM. COVID-19 and the Unraveling of Experimental Medicine Part I. G Med Sci. 2022; 3(1): 015-045.

https://www.doi.org/10.46766/thegms.pubheal.22012306

Copyright: (c) 2022 K. E. Thorp, James A. Thorp, Elise M. Thorp. This is an Open Access article distributed under the Creative Commons Attribution License, which permits unrestricted use, distribution, and reproduction in any medium, provided the original work is properly cited. use, distribution, and reproduction in any medium, provided the original work is properly cited.

\section{Introduction}

Two years into the pandemic, with the number of deaths over five million globally and vaccine-resistant variants continuing to multiply, scientists are in the midst of the most dangerous and ill-conceived experiment in the history of medicine. Pinning their hopes on the success of new mRNA-based vaccines that stretch all conventional notions of a vaccine, and which were hastily released without adequate efficacy and safety trials, they seek to take the wind out of the sails of a full-blown pandemic without fully understanding either the means by which individuals develop resistance to the coronavirus or by which herd immunity is attained.

Throughout the pandemic the vaccine has dominated conversation based on its potential to stimulate the synthesis and release of antibodies that bind to viral antigens and neutralize their effects. Hundreds if not thousands of scientific articles document their role in the COVID-19 syndrome and yet the relationship between such antibodies and long-term immunity remains tenuous at best. The fact that the viral syndrome resolves in a significant number of individuals without antibody production or that they disappear from the serum over a matter of weeks to months raises serious questions as to their role in conferral of long-term immunity.

Equally, the appearance of vaccine-resistant viral strains or breakthrough infection in recently vaccinated individuals draws a clear line between protection and immunity. While the vaccine appears to temporarily boost resistance, it cannot be said to confer long-term immunity. We are thus led to distinguish between antibody-induced protection and natural immunity. This raises questions as to whether mass vaccination will be sufficient to bring closure to the pandemic.

Given such facts it is perplexing that the vaccine issue has taken center stage at the expense of a wider scientific and social dialogue regarding potential solutions. Many physicians have expressed concerns over the efficacy and safety of the vaccine. Numerous others have advocated for prophylaxis and early intervention with cheap and widely available medicines like hydroxychloroquine or ivermectin, both of which have support in the medical literature. The mantra 'evidence-based medicine' has been bandied about in the medical community for decades but it is clear that the current approach to the pandemic is much less about facts and more about perspective.

In this three-part series on the SARS-CoV-19 catastrophe, the first pandemic of the new millennium, we examine the complex interactions between the biological and social domains and how they have so far been impacted by current practices. The outcome of such adjudications will likely influence how future pandemics are approached.

In the present article we examine the dynamic nature of pandemics and raise questions concerning the nature of herd immunity and individual susceptibility. Equally we point to various pandemic-related phenomena that 
researchers have described but cannot satisfactorily explain based on current understanding of immune function. The pandemic has laid bare the cracks and flaws of contemporary medical theory and practice. We advance a dynamic energy-based functional framework to explain various clinical and pathologic phenomena related to COVID-19 infection.

In the second segment we examine broadly implemented approaches intended to limit transmission and spread of the viral vector such as lockdowns, social distancing and masks as well as current hospital-based treatments and examine the role they play in viral-mediated dynamics. We examine the new vaccines and the impact they have had on the evolution of the pandemic. Finally, in the third installment we examine the path not taken, the overlooked home-based treatments that provide a highly effective alternative to institutionally-sponsored modalities which, when implemented in a timely fashion, dramatically reduce pandemic-related morbidity and mortality.

\section{Into the Abyss}

The COVID-19 pandemic, caused by the severe acute respiratory syndrome coronavirus-2 (SARS-CoV-2), began in early 2020 and has persisted for nearly 2 years. Like earlier pandemics it has recurred in a series of waves which have been ascribed to seasonal influences and to the appearance of new viral subtypes but, unlike the influenza pandemics, which typically lasted for 18-24 months, the COVID-19 contagion seems destined to persist well into the 2-3 year range if not longer [1].

All pandemics - a term used to indicate global spread of disease-share common features: they usually begin abruptly and unexpectedly, often in the winter months, frequently in Asia, and continue in a waxing and waning pattern until they spontaneously self-extinguish, which is attributed the rise of herd immunity, a widespread state of resistance to the infectious agent. It is presently unknown what percentage of recovered persons in a population is necessary to attain such a refractory state.

Whether the infectious agent is influenza or SARSCoV-19 all pandemics are driven by the same dynamics: spontaneous emergence of an antigenically novel viral strain or subtype possessing an optimal blend of transmissibility (infectivity) and virulence (pathogenicity) that spreads and interacts within a population of susceptible individuals. Both attributes in tandem are essential: many viral strains freely disseminate but lack pathogenicity; others, like the original SARS-CoV in 2004, are highly virulent but lack the capacity for rapid spread. Since the overwhelming majority of infected individuals develop immunity to the virus it is axiomatic that virulence is inversely related to resistance and only represents a heightened state of susceptibility $[2,3]$.
Viral replication occurs only in susceptible cells. Infection begins with attachment of a viral particle to the cell membrane during which its antigenic surface element, the so-called spike protein, binds to specific receptors. SARS-CoV-2 attaches to the ACE-2 receptor, the same entry vehicle employed by the original SARS virus. A recent study found that the affinity of SARS-CoV-2 for the ACE2 receptor is $10-20$ times that of the original SARS which accounts for its heightened infectivity. Upon attachment the virus enters the cell, sheds its coat releasing its RNA cargo, and initiates the replication process. Newly formed RNA strands self-assemble and acquire envelopes and spikes from the cytoplasm and/or cell membrane. Within hours after infecting the cell a single viral particle can generate hundreds of virions which emerge from the cell and seek out susceptible cells to infect [4-6].

Either during or between pandemics, the virus continues to interact with its hosts which become an eternal reservoir. It evolves and morphs on the basis of spontaneous mutations in its glycoprotein surface coat which consequently alter its infectivity or virulence. This ongoing, largely invisible zoonotic experiment is called antigenic drift. While most spontaneous viral mutations end as failed experiments every so often a new subtype emerges that possesses enhanced transmissibility or virulence thus forming the basis for new waves within a pandemic or epidemics in between pandemics. Epidemics usually remain geographically and temporally confined due to a wall of pre-existing immunity among individuals within the population $[7,8]$.

Confounding pandemic-related issues is the black box problem, the sheer impermeability of the pandemic to statistical analysis. The actual number of cases and mortality rates can never be known and any tally is only a crude estimate. Asymptomatic infections, underreporting of mild viral syndromes, inaccessibility to organized healthcare, and the disinclination of many to report the illness obscure the true magnitude of COVID-19 in the population. This leads to underestimation of prevalence and inability to accurately gauge mortality rate [9-11]. As in earlier influenza pandemics actual infection rates are believed to be at least 3-4 times higher than the reported caseload [12-14].

The dynamically evolving landscape of the pandemic acts as an ever-present destabilizing force that inevitably thwarts ad hoc social measures intended to control viral spread. As the number of cases surges so too does antigenic drift and the potential for emergence of variants with enhanced transmissibility and virulence. Chance mutations in the SARS-CoV-2 spike protein may confer upon it the capacity to evade neutralizing antibodies and gain more easy entry into cells [15-19]. Such new variants are now in circulation. To compound the problem there is uncertainty as to the duration of vaccine-mediated antibody-induced protection [20-22]. 
Factors described above highlight the impossibility of containment of viral spread. Humans, now a primary reservoir for COVID-19, insidiously transmit the virus. Individuals who do not develop symptoms do not necessarily escape infection and individuals who develop infection shed the virus for variable periods, both before the onset of symptoms and often for weeks afterward [2326]. This ignores the contribution of animal reservoirs. By the time a local outbreak is recognized, such as the recent omicron variant, it has already been circulating for weeks and in short order other scattered outbreaks are belatedly recognized. Presently in the US the majority of newly reported cases with the omicron variant are in fully vaccinated individuals [27-30].

Broadly applied interventions such as masks, lockdowns and social distancing temporarily alter transmission dynamics, producing flattening of incidence curves, i.e., the number of newly infected individuals in a specified time period, but do not affect resistance or immunity. It is relevant in light of current social measures enacted during the COVID-19 outbreak that such policies were regarded as ineffective during earlier influenza pandemics [31]. By the same token, mass vaccination programs may produce curve flattening by temporarily boosting resistance; breakthrough infections in vaccinated populations, however, are widely recognized suggesting vaccines do not confer long-term immunity [32-35].

As viral mutation rates increase the length of vaccineinduced protection conversely shortens and breakthrough infection rates begin to climb. Under such conditions how does herd immunity gain a foothold in the population [36]? A related issue concerns the problem of 'leaky' vaccines: they confer protection but allow continued transmission of the virus and potential emergence of highly virulent strains. Such dynamics are present in other viruses [3739].

Attempts to control the pandemic amount to a neverending game of one-upmanship with scientists continually in search of new vaccines that, inevitably, will be rendered ineffective via antigenic drift. Mass vaccination attempts to hit a rapidly-moving target but invariably leads to round after round of booster initiatives nipping at the heels of newly-emergent variants.

Of equal concern regarding such new variants is the phenomenon of reinfection in previously COVID-19 infected individuals. Reports of second and third rounds of infection in previously infected individuals have appeared [40-49]. That individuals successfully overcame a primary infection and were subsequently reinfected points squarely to rapid evolution of the virus. Most reinfections are mild and, if anything, only serve to boost pre-existing immunity. Nonetheless it is further evidence for antigenic drift and raises questions as to what is yet to come.
The silver lining inside the reservoir problem and impossibility of containment: individuals with asymptomatic or mild infections freely disseminate the virus and, ultimately, serve as a primary means by which herd immunity is attained. Given that up to $90 \%$ of infected individuals are either asymptomatic or mildly affected it seems only logical to employ this vast pool of individuals in the quest for herd immunity especially since it is going to occur in any event. The silent spreaders - the asymptomatic, mildly affected, and unvaccinated-serve to enhance collective resistance within the viral reservoir.

In Influenza: The Last Great Plague, William Beveridge notes that in the severe influenza pandemics of the $20^{\text {th }}$ century up to $50 \%$ of the population never developed manifestations of the disease [50]. Some of this is likely related to asymptomatic and mild cases that were never reported but this factor alone seems unlikely to account for such a large portion of the population. At the time of this writing (12/21) there were $266,504,411$ reported COVID-19 cases across the globe which, given a population of 7.8 billion, translates to only about $3.4 \%$ of the population. In the US the corresponding figure is $14.6 \%$ based on $48,982,584$ reported cases out of $333,781,277$ people [51]. Why are infection rates this low if SARS-CoV-2 is so transmissible?

One large meta-analysis with over 77,000 subjects examined secondary transmission within households and found an overall secondary infection rate of $16.6 \%$ with a range from $15.4-22.2 \%$. Transmission rates were higher in symptomatic versus asymptomatic cases, adult versus children contacts, among spouses than other family members, and in households with one contact versus three or more contacts [52-54].

Such unexpectedly low rates of transmission implicate preexisting innate immunity within broad segments of the population. A recent study found humoral immunity in the form of reactive antibodies to the SARS-CoV-2 spike protein in previously uninfected individuals [55]. Such innate protection is especially prevalent in children and adolescents, a population in which symptom expression is typically either absent or mild. This background of resistance in selected individuals likely forms the basis of herd immunity and it is this innate capacity which must be expressly amplified in the population in order to bring the pandemic to a halt. Given such considerations why would scientists immunize children against COVID-19 infection?

One the most glaring epidemiological features of the COVID-19 pandemic (and of earlier influenza outbreaks) is the problem of differential susceptibility. Why are certain segments of the population so disposed to developing severe disease while others such as children are minimally affected? How does one account for the disproportionate morbidity and mortality among the elderly, males, certain 
ethnic groups, and those with pre-existing conditions like obesity, hypertension, diabetes, and chronic conditions such as cardiac and renal disease [56-73]? It is puzzling that this disparity has not raised more eyebrows much less demanded satisfactory explanation for it points unambiguously in a direction that virologists and vaccinologists seem to have overlooked.

In a recent clinical study, we established for the first time in contemporary medical science the existence of a complex electromagnetic field in the human body [74] and in subsequent papers documented the dynamics of an aether-mediated energy field taking origin in the cardiovascular system through the contraction and dilation of the heart [75-77].

During systole electrical currents streaming through cardiac nerves are infused into the heart muscle and blood and, through interaction with iron stores in these tissues, induce generation of a magnetic field and subsequent outward diastolic motion of the cardiac and arterial walls. Such outward movement generates negative intraluminal pressures, i.e., a suction force, which draws blood forward through arteries and veins thus accounting for spiral flow currents seen in these vessels [78-85].

It has been recognized since the 1980s that diastole is the primary and determinant phase of the cardiac cycle [8688]. This is so because it is the period of active energy infusion into the blood. Impaired outward motion of the heart and arterial walls, known as diastolic dysfunction, is prima facie evidence of diminished energy influx into the blood. Numerous reports link diastolic dysfunction to diverse conditions like obesity, hypertension, diabetes, coronary artery disease, autoimmune disease, chronic heart failure and chronic kidney disease, the very same conditions associated with increased morbidity and mortality rates after COVID-19 infection [89-113]. All these conditions, as well as the COVID-19 syndrome itself, including both symptoms and cellular disturbances, reflect a primary energy deficiency in the blood-borne energy field.

Not only has the pandemic caught science off-guard and unprepared but it has revealed grave deficiencies in current medical theory and practice. The existence of a bloodborne energy field in living bodies was first described by Roman physician Galen around $200 \mathrm{AD}$ and had been accepted as fact by all physicians until it was arbitrarily discarded by experimental scientists in the $18^{\text {th }}$ century. To make matters more complicated, the reigning immune theory, first advanced around the turn of the $20^{\text {th }}$ century, has been unable to account for phenomena commonly associated with COVID-19 infection and scientists are now back-pedaling and waffling. The pandemic has shaken the foundations of cellular and molecular science.

\section{The Antibody Problem}

In the years surrounding the turn of the $20^{\text {th }}$ century when modern immune theory took shape, experimental immunology was bitterly divided between two scientific factions, a group of biologically oriented experimentalists at the Pasteur Institute in Paris, under the influence of Jules Bordet, who asserted the primacy of cellular events in the immune response, and a German camp, under the lead of Paul Ehrlich, who forcefully argued for the primacy of antibodies as the determinant mechanism in the expression of immunity.

As immunologist Arthur Silverstein points out in his acclaimed work A History of Immunology, the two groups conducted intellectual warfare in the scientific literature seeking to undermine the other's position, in many cases performing the same experiments, and attempting to demonstrate how their own theory was better able to explain results. By the end of the first decade of the $20^{\text {th }}$ century the molecular perspective had gained a decisive edge and the cellular orientation fell into disfavor for the next half-century, a period Silverstein calls the Dark Age of experimental immunology [114].

Even within the ascendant molecular camp agreement was far from unanimous. Ehrlich, domineering and dogmatic, one of the early architects of cell receptor theory, argued that the antigen-antibody interaction at the cell surface was based on specific lock-and-key chemical interactions. Over the course of evolution, he claimed, living organisms had acquired an immense antibody repertoire that, during infection, was secreted by immune cells to defend against toxins and bacterial invaders.

By the early $20^{\text {th }}$ century tens of thousands of antigenic substances had been discovered, including many newly synthesized in the laboratory, and various scientists argued that evolution could not have possibly equipped living organisms with a such a vast repertoire of antibodies against an endless array of antigens, some of which had not even been in existence until recently. Researchers like Karl Landsteiner, discoverer of the ABO blood groups, argued against specific lock-and-key chemical interactions and, instead, for a much smaller number of antibodies with overlapping specificities.

Landsteiner asserted that electrochemical forces, not chemical interactions, mediated specific affinity and were the basis of the immune response. Antigenantibody precipitation reactions were easily explained by colloidal interactions. He and his co-workers found that charged acidic and alkaline colloids not only moved in opposite directions in electrolysis experiments but actively precipitated each other. Interactions were based not on chemical constitution but on physical properties like $\mathrm{pH}$, solubility and temperature. It seems, Landsteiner wrote, 'that this extraordinary type of reaction plays a 
particularly large part in living organisms; living substance is mostly made up of colloids' [115]. Landsteiner's claims are now recognized to be correct [116].

Figure 1. Three-dimensional representation of antibody structure. Red dots indicate binding regions.

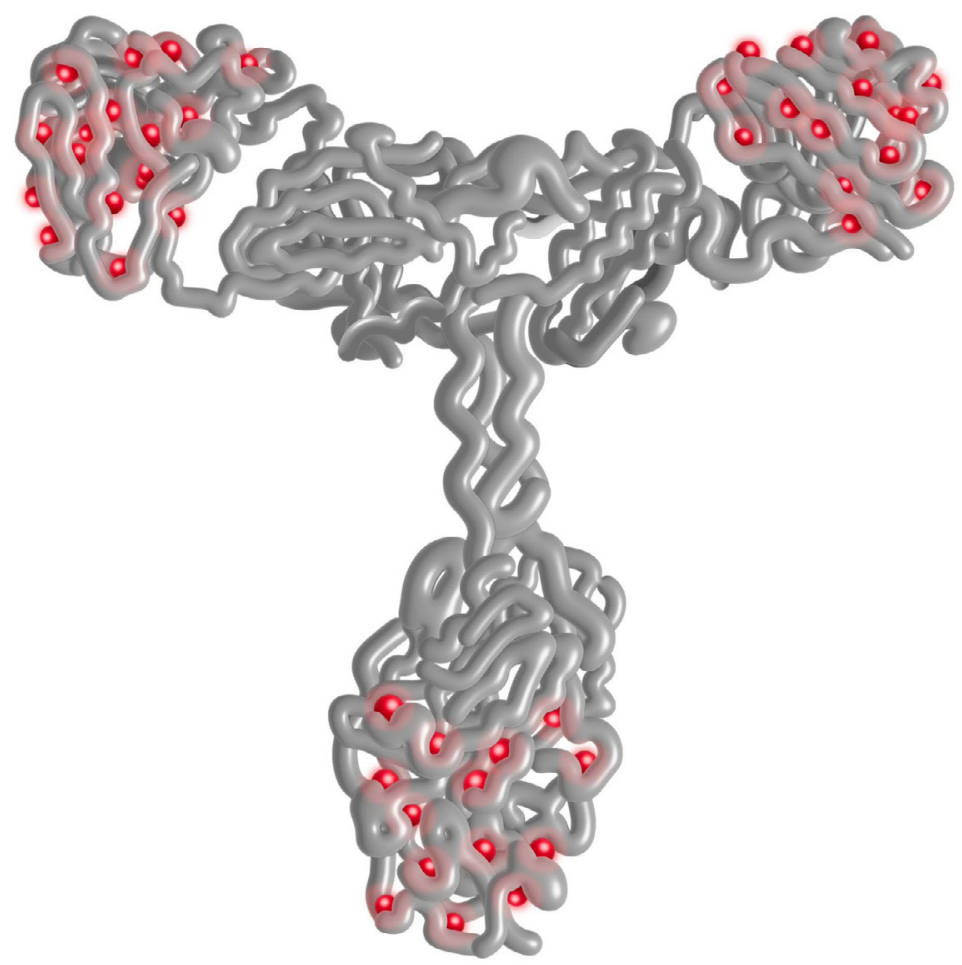
STEVE BARSHOV

The antibody is a Y-shaped protein composed of four polypeptide chains, two elongate heavy chains arranged side-by-side forming the ' $\mathrm{Y}$ ' and two light chains in the limb regions of the ' $\mathrm{Y}$ ' in parallel with the heavy chains (Figure 1). Functionally it is divided into two polar regions, one in the branched limbs, the antigen-binding site (Fab), which, as expected, is highly variable in amino acid composition and the other, forming the trunk of the ' $\mathrm{Y}$ ', the constant region $(\mathrm{Fc})$, possessing highly conserved amino acid sequences, which binds to immune effector cells and activates various functions including breakdown of the antigen. At the junction of the trunk and limbs of the ' $\mathrm{Y}$ ' is a highly flexible area, called the hinge region, which allows for maximal three-dimensional (3-D) movement of the trunk and limb regions to enable binding of the antibody to both antigen and immune cells [117-119] (Figure 2). 
Figure 2. Depiction of functional antibody regions. Two Fab limbs for antigenic binding. The Fc fragment attaches to immune effector cells. The highly flexible hinge region allows for maximal conformational plasticity.

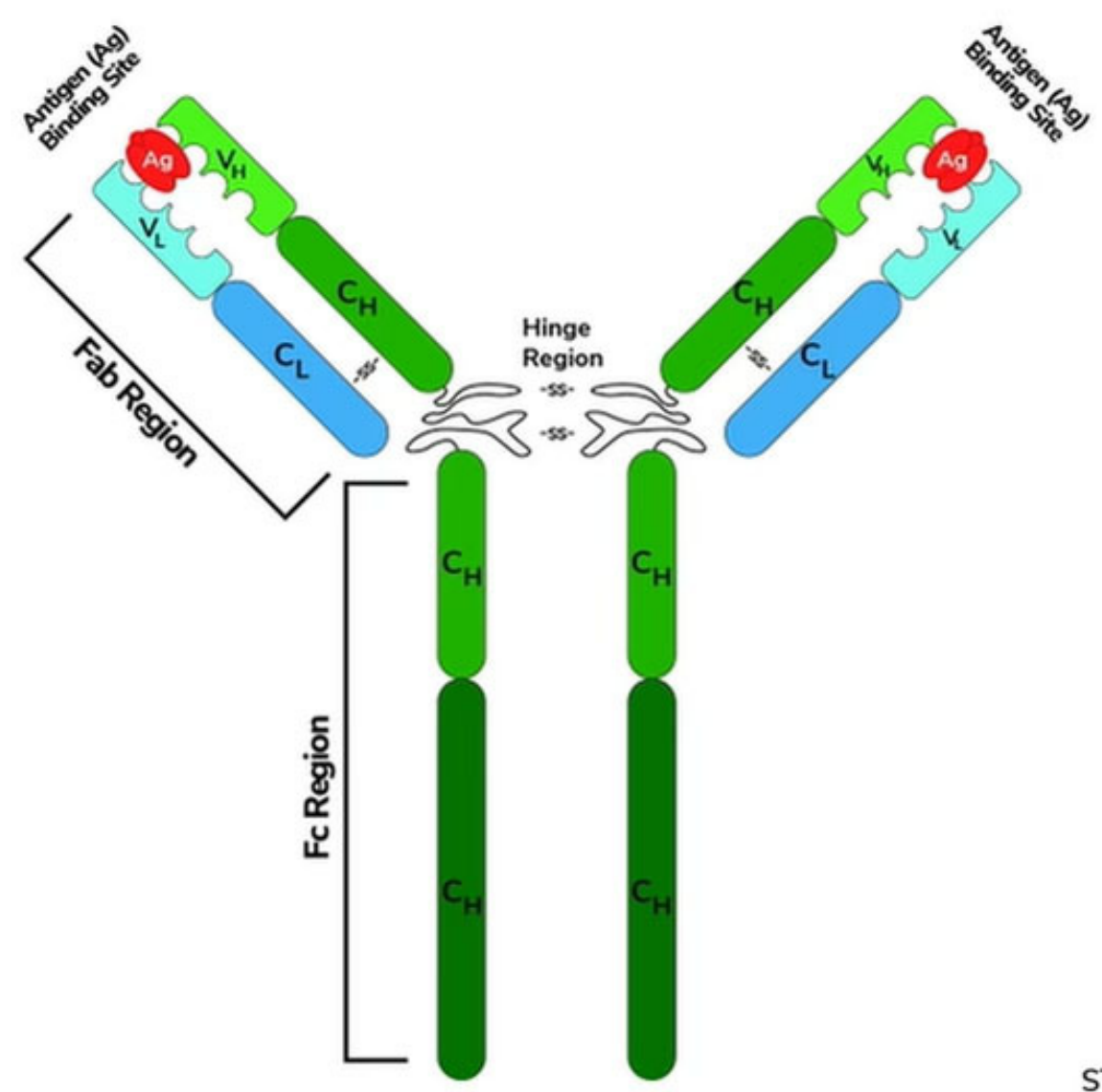

While the linear structure of the heavy and light chains is formed by covalent chemical bonds, the parallel relationship between the two chain types, as well as the overall 3-D configuration of the antibody, is energetic in nature, a result of ionic attraction/repulsion, van der Waals forces, and hydrogen bonding. The polar configuration of antibodies with binding sites for antigens at one end and cell membrane receptors at the other allow for the formation of complex interactions between antigens and cells in which such complexes undergo complex conformational changes that affect cell function. The higher order structure of proteins as well as flexibility and capacity to undergo conformational change is explained largely by their hydrogen bond networks [120-126].

The ability of proteins to dynamically modify their conformation is called allosterism. In such interactions proteins reorganize their spatial configurations togenerate dynamic linkages between widely separated domains. In antigen-antibody interactions such interplay requires energetic coupling both within the protein as well as with the antigen and cell receptor. For decades it was widely believed, based on Ehrlich's lock and key hypothesis, that allostery was mediated through structural analogues on adjacent proteins, but recent studies indicate it is driven solely by energy dynamics [127-136].

It is now acknowledged that a limited repertoire of antibodies is able to interact with an almost endless array of antigens. This is possible since the determinants of such interactions are commonly shared energetic properties distributed over the protein surfaces both at and away from the binding site. In the hydrophilic regions of the complexes, for example, positively- and negativelycharged sites may be drawn into close apposition while two adjacent negatively-charged sites may repel, the degree of attraction and repulsion determined solely by charge strength and distance. All conformational change is energy dependent [137-150].

By the same token binding of the virus to the cell surface is energy-driven. Studies of the SARS-CoV-2 spike protein describe multiple distinct conformational states with different 3-D receptor-binding domain conformations that confer on its exceptional plasticity and adaptability. This property likely accounts for the rapid emergence of new variants. Viral mutations affecting key regions in the spike protein can alter energy distribution and topography 
at the binding site allowing for enhanced entry into the cell. Such mutations, in turn, induce conformational changes in the ACE-2 receptor on the cell surface via fluctuations in the conjoined hydrogen bond network with resultant alterations in rigidity and flexibility throughout the complex [151-156].

Such dynamics explain antibody-dependent enhancement (ADE), recognized earlier in the SARS-CoV and MERS$\mathrm{CoV}$ outbreaks and more recently in the SARS-CoV-2 pandemic. It was observed in certain cases that upon attachment of the Fc antibody region to the virus its ability to enter the cell and replicate was paradoxically enhanced with resultant disease severity. $\mathrm{ADE}$ has been attributed to poorly neutralizing or non-neutralizing antibodies, i.e., loss of affinity between antibody and virus. At least five structurally-based mechanisms for ADE have been proposed all involving functional changes at the cell surface [157-165]. Occam's razor, which dictates that the simplest answer is usually correct, would point to conformational changes induced by energy deficiency. Such functional incapacity falls under the general rubric of a protein misfolding disorder or what is also called the intrinsically disordered protein state [166, 167].

The common denominator for the various energymediated transformations involved in antigen-antibody interactions lead, in turn, not back to the cell and genome but rather into the interstitial fluid space which channels energy between the vascular and intracellular compartments. In recent decades there has been an explosion of research in the physical sciences using $\mathrm{x}$-ray scattering, NMR spectroscopy, and x-ray crystallography to study protein structure and folding dynamics. All the various methods substantiate the key role played by water in protein-related dynamics [168-177].

To be biologically active proteins, i.e., antigens and antibodies, must acquire a so-called hydration shell consisting of multiple surface layers of water molecules often extending up to $25 \AA$ from the protein surface. This fluid layer appears to be a critical determinant not only of 3-D protein structure but the folding process itself. Protein misfolding and the intrinsically disordered protein state are mediated via interactions with water. The hydration shell surrounds hydrophilic domains of most proteins and cell membranes and spontaneously organizes into a complex hexagonal lattice-type arrangement, which researchers liken to a semi-crystalline state. Hydration shell water has physical properties distinct from that of surrounding extracellular water including net negative charge, higher $\mathrm{pH}$ and increased density resulting in electrical potentials and current flow. The centrality of colloidal dynamics, first advanced in the early $20^{\text {th }}$ century but ignored by cellular and molecular biologists, is now widely acknowledged [178-182].
There are other compelling reasons beyond the energy equation to question the primacy of antibody-related processes in conferral of immunity. Following COVID-19 infection, antibodies rarely appear in the blood before 12 days and sometimes not for 21 days. In many cases symptoms subside before antibodies even appear. Antispike protein IgG antibody levels, on the other hand, wane over weeks to months post-infection and by 3-5 months may be negligible [183-192]. By contrast, studies find antigen-specific memory B-cell levels can remain unchanged for 6 months after infection [193]. Such evidence points away from antibodies and toward cellular dynamics in the establishment of long-term immunity.

These conclusions are substantiated by a recent pandemic-related discovery: a significant portion of the COVID-19 infected population, as confirmed by positive polymerase chain reaction tests, never develop a systemic antibody response. Such 'nonseroconverters' range from a low of $5 \%$ in one study to a high of $36 \%$ in another; three other studies found no seroconversion rates in the 15$25 \%$ range. Nonseroconverters tend to have lower disease severity, more rapid viral clearance and lower blood inflammatory marker levels [194-199]. Findings point to the critical role non-lymphocytic WBC subsets like macrophages and neutrophils play in the early immune response. Other evidence points squarely in the same direction.

Individuals with more severe disease have higher neutralizing antibody levels than asymptomatic or mildly affected cases [200-219]. Hospitalized individuals have neutralizing antibody levels up to 3000-fold higher than less affected or recovered subsets [220-223]. No satisfying explanation has emerged. Another study found obese individuals with the metabolic syndrome, the same population with worse clinical outcomes, also have higher antibody responses [224]. This is to say that mildly affected and asymptomatic individuals, those with the best clinical outcomes, paradoxically have the lowest antibody responses.

Such findings make no sense unless one accepts that antibodies have only a supporting role in the immune response. Based on available evidence it seems more likely that antibody production is a fallback strategy implemented when primary cellular immune mechanisms are deficient. This inconvenient fact overturns Ehrlich's 120-year-old antibody hypothesis. By the same token it explains why currently employed vaccines stimulate antibody production and confer protection but don't induce immunity.

\section{Internal Digestive System}

In the 1880s while studying transparent star-fish larvae under the microscope, biologist Elie Metchnikoff 
observed cells which appeared to wander about in the tissues. Suspecting they played a role in the breakdown of substances; he introduced a rose thorn into the larva and observed that it was soon surrounded by these mobile cells. Calling them phagocytes or 'eating cells,' he claimed that the functions carried out by these cells was part of a primitive body-wide digestive function that included active host defense [225-227].

Later Metchnikoff injected anthrax bacilli beneath the skin of frogs, which are immune to anthrax, and observed them being engulfed and destroyed by WBCs. Metchnikoff argued that phagocytes play a primary role in host defense and resistance to disease. In a series of papers, he outlined his phagocytosis theory: wandering phagocytic cells possess diverse but functionally aligned processes related to intracellular digestion, namely, engulfment and breakdown of aged or injured host tissue or invading micro-organisms; tissue macrophages and WBCs play a primary role in this integrated functional system; host defense is based on successful containment of pathogens by the phagocytic system. Around the turn of the $20^{\text {th }}$ century Jules Bordet, ardent supporter of phagocytic theory, wrote, 'one of the most significant conclusions that is derived from the work of Metchnikoff is that immunity is a special case of digestion.'

In the $2^{\text {nd }}$ century Roman physician Galen argued that the stomach and spleen formed a nexus of functions related to digestion. From a modern perspective we can conceive these two organs as forming an integrated functional cycle: the stomach initiates digestion of food materials taken in from the outside which, through the blood, are distributed to all parts of the body. The spleen and phagocytic cells on the other hand, initiate the breakdown of substances inside the body and return them via the blood to the liver for recycling and intestines for elimination.

The common link between the internal and external digestive systems is generation of acid and acid-based enzyme systems that catabolize organic materials. Neutrophils and macrophages contain granules laden with digestive enzymes and substances like defensins and cathelicidins that incapacitate bacteria and viruses. The internal digestive system, independent of antibodies, inhibits replication of bacteria and viruses, performs housekeeping functions, and triggers repair of injured tissue. Antibody production is far downstream from where the real action is.

Two main phagocytic cell lines, macrophages and neutrophils (PMNs), carry out digestive functions in the interstitial fluid spaces exactly as Metchnikoff described [228, 229]. Their primary role is engulfment and breakdown of foreign materials, damaged cells and macromolecules [230-233]. Owing to their strategic location in the interstitial fluid compartment macrophages form the tip of the immune spear and play a key role in initiating and terminating inflammatory responses (Figure 3 and Figure 4).

Figure 3. Macrophage under transmission electron microscopy.

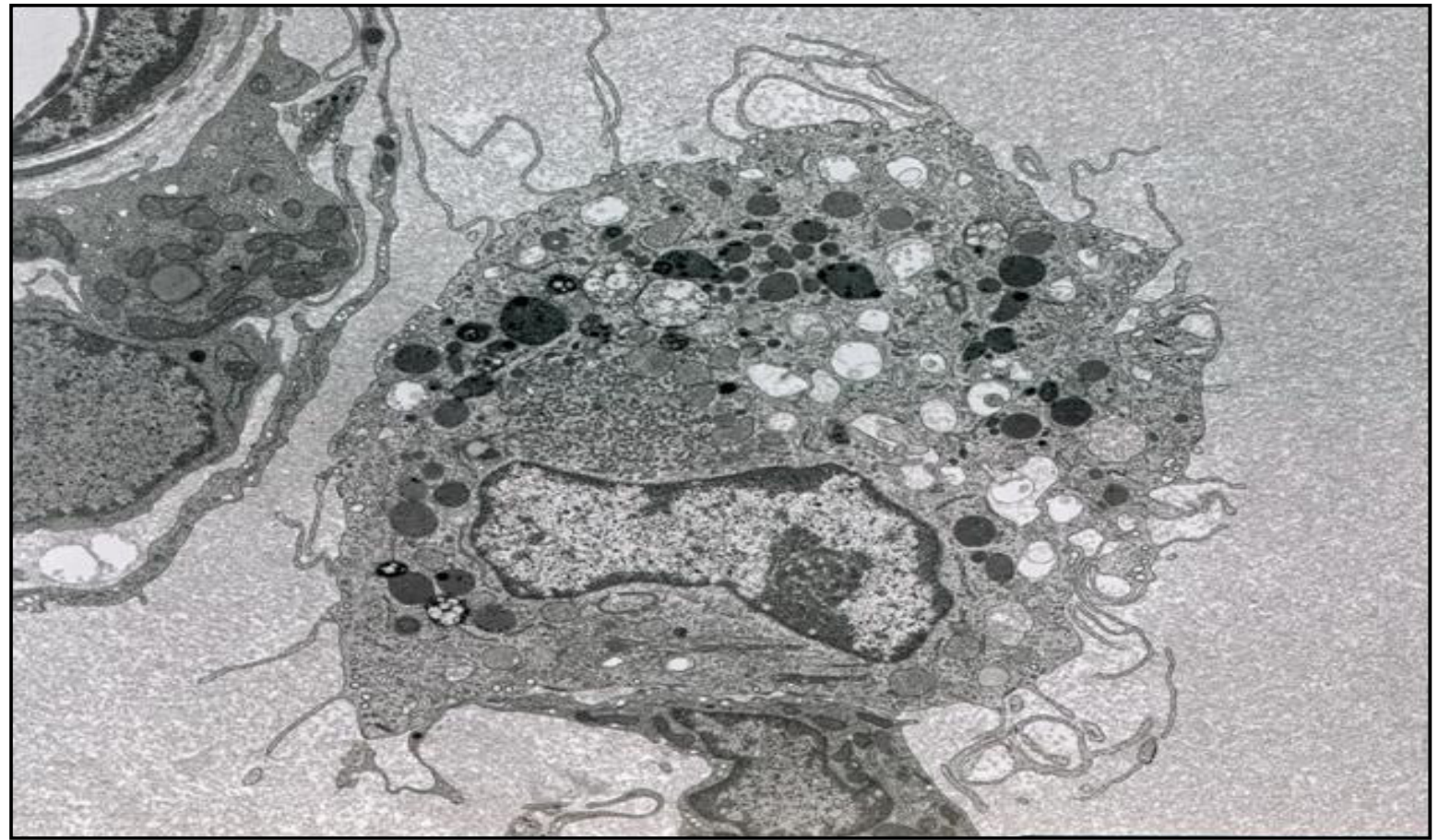


For decades immunologists arbitrarily distinguished between two types of immunity, so-called innate and adaptive forms, one concerned with more general functions and the other with specific antibody-directed defenses. It was widely believed that only adaptive immunity, i.e., the antibody generating subset, possessed memory capable of specific recall of foreign substances but this has been found to be incorrect. Cells of the innate immune system, i.e., macrophages, also acquire new memory-based responses, known as trained innate immunity, that enhance resistance to antigens. The decades-long distinction between innate and adaptive immunity is thus artificial [234-236].

Even the long-held dictum that the primary immune function was to discriminate between self and non-self has come into question. Immune cells like macrophages respond functionally to changing cytokine and metabolite levels in their local milieu, so-called damage-associated and pathogen-associated molecular patterns (DAMPs and PAMPs). Macrophages are highly plastic and, even after differentiating into a particular functional subset, retain the ability to reprogram in response to changing environmental conditions. Consensus has shifted toward the notion of a dynamic, epigenetically-driven state of balance between environmental factors, gene expression and immune function [237-241].

Two opposing functional cytokine groups, pro- and anti-inflammatory, direct all WBC activity and induce macrophage polarization [242-244]. Macrophages form two subsets: pro-inflammatory M1 type polarized by cytokines such as interferon (IFN-y), tumor necrosis factor (TNF- $\alpha)$, interleukin IL-1 $\beta$, IL-6, IL-12, and IL23. Anti-inflammatory $M 2$ macrophage cells, conversely, are activated by IL-4, IL-13 and, in turn, produce antiinflammatory cytokines like IL-10 and transforming growth factor (TGF- $\beta$ ). The same pro-inflammatory/ anti-inflammatory dichotomy is seen in T-helper Th-1 and Th-2 lymphocyte subsets [245-247].

In the early 1950s Belgian cell biologist Christian de Duve described an intracellular membrane-bound organelle he called the lysosome. Later, under the electron microscope, he observed delivery of cellular materials into lysosomes and coined the term autophagy, meaning 'self-eating,' to designate intracellular digestion [248, 249]. In autophagy acid is concentrated in lysosomes and catabolic enzymes activated not unlike that which occurs in the stomach. Autophagy culls aging and damaged cell structures and generates energy during periods of nutrient deficiency [250].

In recent decades impaired autophagy has been associated with a large and growing number of acute and chronic diseases involving inflammation like autoimmune and infectious diseases including COVID-19 [251-263]. From the early $20^{\text {th }}$ century onward scientists never clearly defined what 'immunity' actually was. Autophagy is the cornerstone of immunity and forms the primary defense against infection as Metchnikoff asserted 130 years ago. Asymptomatic and mild COVID-19 infections, rather than paradigms of heightened 'immunity,' are a result of robust autophagy.

Scientific articles thus suggest autophagy-enhancing substances to treat COVID-19 [264-268]. But autophagy is an energy-requiring process and many symptomatic cases already have impairment of mitochondrial function [269275]. Such conjoined cellular energy defects involving mitochondria and lysosomes in cells throughout the body, including immune cells are, in fact, precisely what drives inflammation [276-287].

Many infectious agents, including SARS-CoV-2, gain access to the body by colonizing epithelial cells where they attempt to reproduce and disseminate. The primary cellular response to such incursions is induction of autophagy. Microbes are enveloped in a membrane, the phagosome, which fuses with the acid-laden lysosome to initiate the decomposition process. If autophagy in epithelial cells is effective then spread of the infectious vector is prevented; in cases where it is not the agent reproduces, initiates cell lysis, and spills into the interstitial fluid space. During cell lysis, DAMPs and PAMPs as well as cytokines like IFN-y are released which elicit a local macrophage response [288-290].

Activated macrophages converge at the infection site and initiate phagocytosis to contain further spread. Macrophages possess a multitude of acid-driven mechanisms by which to dispose of the infectious vector: the agent is walled-off in a sealed membrane limiting access to nutrients; release of polypeptides like defensin and cathelicidin destroy the outer bacterial membrane; acid and metals within the phagosome trigger the organism's own self-digestive enzyme systems; the catabolic degradation process amplifies to produce highly reactive substances like nitric oxide and free radicals which further degrade the ingested particle (Figure 4).

If such autophagy-driven mechanisms are successful then spread of infection is prevented and the inflammatory response is terminated via cytokine flux. If, however, the response is deficient then macrophages release additional pro-inflammatory cytokines to elicit support from circulating PMNs and lymphocytes in the blood, the so-called humoral or blood-mediated response. Spread of an infectious process thus involves successive breaches of barrier functions, first in epithelial cells, then macrophages in the interstitial fluid space, related to impaired autophagy. The humoral phase of the response is an attempt to enhance digestive functions by drawing energy and other blood-borne resources to the site of infection. 
Figure 4. Sequential depiction of phagocytosis: 1) engulfment; 2) formation of membrane-bound phagosome; 3) fusion with cytoplasmic lysosomes; 4) internal digestion; 5) elimination of waste.

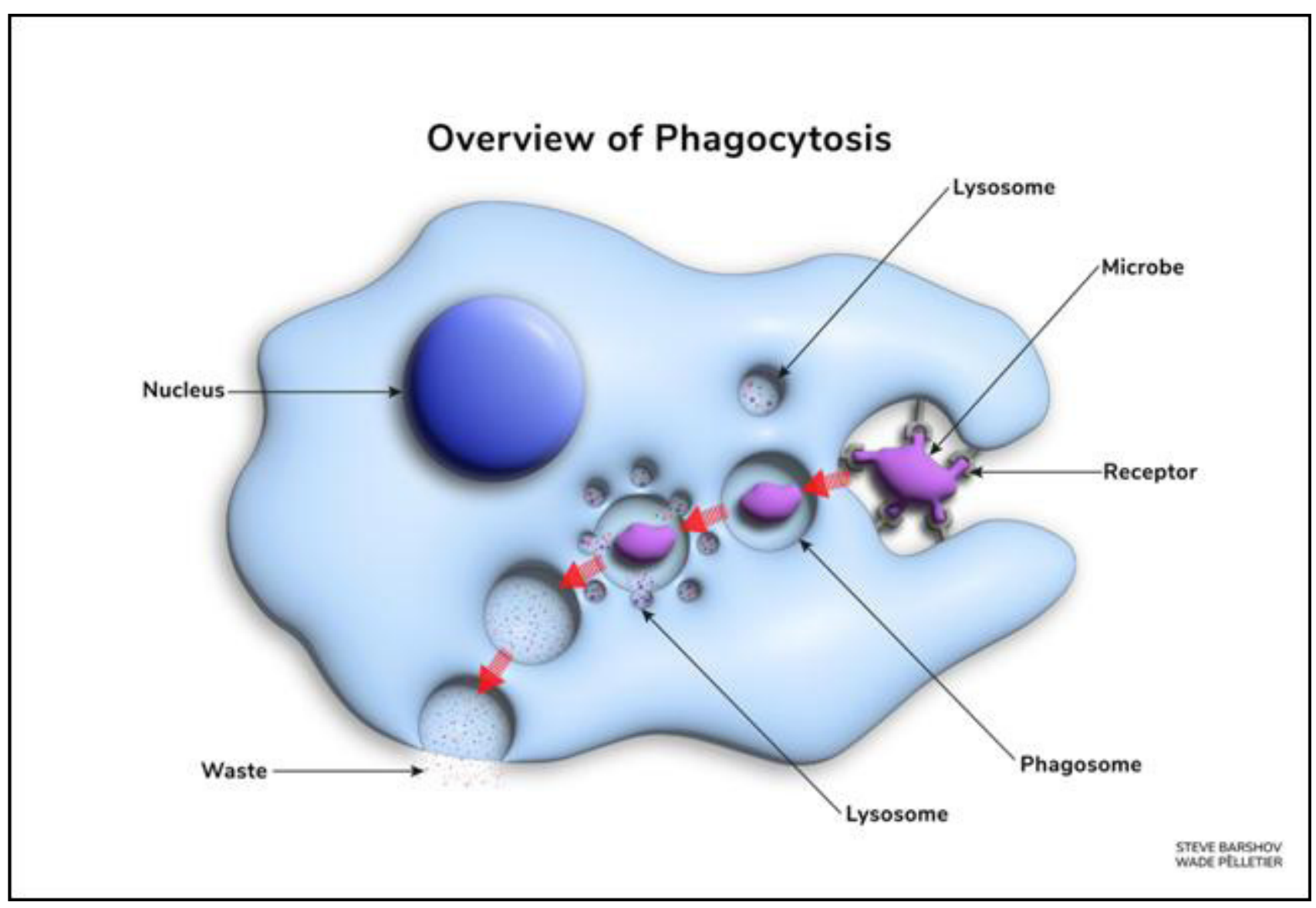

\section{Runaway Inflammation}

COVID-19 infection is characterized by three stages: the latent phase during which viral replication and dissemination is punctuated by the release of cytokines and elicitation of the cellular immune response; the amplification phase during which the interaction between viral and immune dynamics becomes systemic resulting in symptomatic and physiologic alterations; the depletion phase in which intravascular energy generation is profoundly impaired with runaway immune-mediated inflammation that triggers spiraling deterioration of clinical and physiological parameters [291-293]. Progression through the three stages is not invariable and disease outcome can be favorably altered by appropriate interventions early in the course of the syndrome.

To understand the complex web of relations that drive runaway inflammation in COVID-19, we must go back to the beginning, both in terms of disease process and the history of medicine. Roman physician Galen, the great western medical synthesizer, unified and systematized all medical knowledge from the time of Hippocrates onward. The primary basis for his humoral system is a bloodborne energy field which mediates all bodily functions.
This amounts to saying that all dysfunction is secondary to diminished energy generation by the heart. COVID-19 is a latter-day poster child for Galen's humoral medicine. Functional disturbances associated with COVID-19 infection are mediated by diastolic dysfunction originating in the cardiovascular system and blood. Studies indicate that vascular endothelial cells become infected by SARS-CoV-2 with resultant widespread endothelial inflammation in advanced COVID-19 cases. This has led various researchers to question whether the cardiovascular system plays a primary role in the systemic dynamics of the syndrome [294-301].

The endothelium forms an interface between the blood and peripheral tissues that orchestrates energydriven functions like vasomotion, vessel permeability, hemostasis, coagulation and fibrinolysis. Diastolic and endothelial dysfunction is widely believed to not only impair organ perfusion but to augment the systemic prothrombotic state resulting in arteriovenous macro- and micro-thrombotic events.

The ubiquitous distribution of the vascular tree accounts for the wide range of symptoms and functional deficits from person to person with apparent random involvement of multiple organs like the lungs, heart, kidneys and brain 
[302-313]. As indicated earlier, diastolic dysfunction is the common link among comorbid states like hypertension, diabetes, chronic heart and kidney disease as well as obesity, all of which increase the risk for severe COVID-19. The presence of widespread endothelial inflammation involving large and small vessels points to a more than casual relationship between runaway inflammation and impaired energy-generation in the vascular compartment. Inflammation represents a cellular response to deficient energy flow across the cell membrane. Diminished intracellular energy induces mitochondrial dysfunction with a shift from aerobic to less efficient metabolic pathways resulting in generation of reactive oxygen species (ROS), accumulation of acidic metabolic byproducts, as well as altered membrane potentials of intracellular organelles including mitochondria and lysosomes [314-320].

The generation of ROS causes structural damage by denaturation of proteins but also induces formation of the stress-related structure known as the NLRP3 inflammasome which is responsible for induction of the pro-inflammatory cytokine storm that accompanies the runaway inflammation of COVID-19. A large body of data indicates that the cytokine storm is associated both with COVID-19 severity as well as mortality rates [321-334]. Blood analysis of COVID-infected patients has shown increased TNF- $\alpha$ and inflammatory interleukins including IL-1 $\beta$, IL-2, IL-6, and IL-10 which amplify the already existing endothelial dysfunction. As others point out, there is not one but two storms, the cytokine storm, secondary to widespread mitochondrial dysfunction and a primary, equally impactful ROS storm [335-343].

For decades clinicians have speculated on a possible relationship between viral infection and subsequent development of autoimmune disease. This association has come to the forefront in the SARS-CoV-2 pandemic with numerous reports of viral-induced effects mimicking various autoimmune syndromes [344-348]. The crossover between the two states is strengthened by laboratory phenomena like autoantibodies, neutrophil extracellular traps, and the macrophage activation syndrome.

As with autoimmune disease, a wide array of autoantibodies (autoAbs) directed against proteins like cytokines, chemokines, complement, cell surface proteins as well as RNA and DNA have been described in SARS-CoV-2-infected individuals. Studies find dramatic increases in autoAb activity which, depending on the species of autoAb, may range from $10 \%$ to as high as $50 \%$. Such autoAbs likely result from protein misfolding related to energy deficiency leading to loss of antigenic specificity and subsequent cross-reactivity with native macromolecules.

AutoAbs further impair immune function by interfering with cytokine signaling and immune cell responsiveness. The presence of autoAbs directed against intracellular structures like nucleic acids points to widescale cell destruction mediated by viral infection and/or cellmediated processes like apoptosis, pyroptosis or necroptosis, all of which point an incriminating finger in the direction of impaired autophagy [349-355].

Neutrophil extracellular traps (NETS), found in abundance in COVID-19 subjects, are web-like fibrinous structures released by PMNs intended to trap and contain typically intracellular structures like mitochondrial or nuclear DNA, enzymes, and histones that have spilled into the interstitial fluid space. NETs, a feature of autoimmune disorders like systemic lupus erythematosus (SLE), augment cytokine secretion and the pro-thrombotic milieu and are major risk factors for lung injury, multiorgan damage, and mortality in COVID-19 disease. They trigger formation of autoAbs which further amplify the spiral of deterioration. The presence of NETS is a direct consequence of impaired autophagy by immune cells. Sera from advanced COVID-19 patients had lower degradation capacity of NETs than less affected individuals [356-368]. Macrophage activation syndrome, a potentially lifethreatening complication of various autoimmune disorders like SLE, juvenile rheumatoid arthritis as well as COVID-19 infection, is characterized by fever, pancytopenia, coagulopathy, hepatosplenomegaly and biliary dysfunction. Through incompletely understood mechanisms the cytokine storm and runaway inflammation trigger activation and expansion of macrophages and NK T-cell lymphocytes. It carries a high mortality rate $[369,370]$.

In advanced COVID-19 cases microthrombi are present in small- and medium-sized arteries in nearly all organs, including the lungs, heart, brain, and liver and these microthrombi contribute to organ dysfunction and ultimately death [371-376]. Nearly all patients with severe COVID-19 present with bilateral lung involvement (Figure 5). Acute onset of impaired oxygenation occurs in up to $40 \%$ of patients with COVID-19 pneumonia and of these about $80 \%$ require supplemental oxygenation and about $30 \%$ mechanical ventilation. In one large metaanalysis mortality rate in patients requiring mechanical ventilation approximated $50 \%$ with rates up to $80 \%$ in the elderly and those with multiple comorbidities [377].

COVID-19-related respiratory failure is caused by severe lung injury similar to that seen in ARDS. Injury is not induced by viral infection or replication per se but rather by the dysregulated immune response directed toward the virus [378]. The dominant pattern of injury is diffuse alveolar damage accompanied by platelet-fibrin microthrombi, collapse of alveoli, dilated alveolar ducts, capillary congestion and scattered alveolar hemorrhages [379-382]. 
Figure 5. The multifaceted appearance of COVID-19 pneumonitis on CT chest scans. Normal appearing lungs upper left.
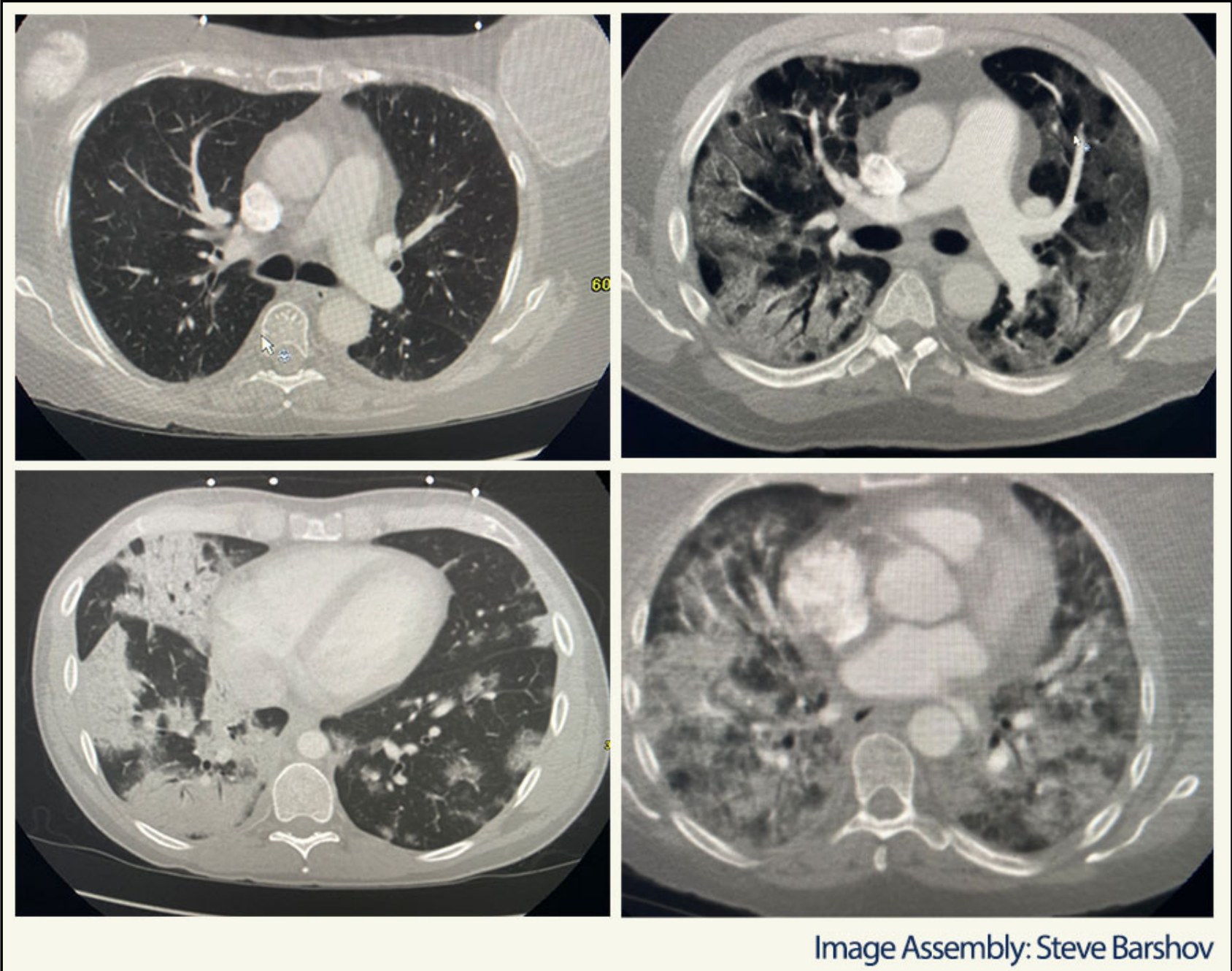

The heart is a common target organ in COVID-19 immunemediated pathology and multiple cardiac complications including myocarditis, myocardial infarct, cardiac dysrhythmias and heart failure have been reported. By the same token COVID-19-induced renal failure and neurologic complications like stroke contribute to worsening morbidity and mortality in severe cases [383392]. Autopsy studies on decedents describe widespread capillary congestion in the lungs and other organs suggesting severe vascular dysfunction [393].

Based on considerations presented in this article in all instances of COVID-19 infection the primary therapeutic imperative should be correction of diastolic dysfunction and energy deficits in the blood, normalization of mitochondrial function to prevent or reverse ROS generation and the cytokine storm and, finally, restoration of impaired autophagy. In the third part of the series, we examine such strategies.

In the current pandemic health care systems have no effective strategy to address SARS-CoV-2 infection early

in its course when it is the easiest, least expensive to treat, and has the best chance of satisfactory outcome. Instead, they left events in this critical window to chance and let matters take their course. From the beginning organized health care set itself up for failure: by the time individuals present to the ED at the local hospital they have often had symptoms for 7-12 days, are in profound energy debt, and already in the cytokine-ROS storm [394]. Each step in the process, from hospital admission, to ICU transfer, to mechanical ventilation, is punctuated by incremental mortality rates.

In-hospital treatment of the syndrome involves steroids to quell inflammation, disease-modifying agents directed at the cytokine storm, anti-thrombotic drugs to inhibit clot formation, and anti-viral agents, none of which address the primary functional events that drive the syndrome and are thus only palliative. This amounts to a profound systemic failure by medical science to appropriately conceive and treat COVID-19 and the SARSCoV-19 pandemic. 


\section{Science on Trial}

Pandemics, devastating, destructive natural occurrences, expose weaknesses and deficiencies of the systems in which they interact. It is fair and accurate to say that the pandemic has been broadly mismanaged at multiple levels. Current events will undoubtedly be debated by scientists and historians for decades to come. Nonetheless, takehome points can be distilled so far from the COVID-19 catastrophe.

In 1973, Charles Cockburn, then head of virology section WHO, wrote: 'the influenza virus behaves just as it seems to have done 500 or 1000 years ago and we are no more capable of stopping epidemics or pandemics than our ancestors were' [395]. At this point, two years into the pandemic, there is little evidence to suggest that social or medical interventions have favorably altered dynamics of the pandemic. Indeed, one could question whether they have made it worse. Scientists miscalculated the relentless nature of the pandemic and what was required to achieve herd immunity, or even what herd immunity is.

One year after introduction of mRNA vaccines, with much fanfare, they seem to have widely missed the mark. While proponents claim it provides protection against the virus, such protection is at best temporary. We have observed breakthrough infections 2-3 months post-vaccination in numerous individuals. Vaccination does not confer longterm immunity. It does not impact transmission of the virus and, moreover, contributes to the emergence of new variants. And this does not address the problem of adverse event rates which are now being more widely recognized. Why weren't such issues properly vetted by scientists before introduction of such experimental and potentially dangerous agents?

Clearly, extensive revisions must now be made to the reigning immune theory. Some would argue that this is the nature of experimental science, which is always in flux, always generating new facts, always seeking new insights. But such is not the case in the COVID-19 pandemic: the problem is far deeper and systemic for it involves a perennial inability of scientists to make critical adjudications in a timely and appropriate manner.

To finally recognize autophagy as the primary basis of the immune response 130 years after it was clearly and presciently articulated by Metchnikoff is an indefensible stain on the experimental method. The same can be said for Landsteiner's argument from early in the $20^{\text {th }}$ century against Ehrlich's lock-and-key chemical basis of antibody specificity. Why weren't such issues vetted more thoroughly by the science community? The current paradigmatic crisis in science is nothing but the chickens coming home to roost.
Equally disturbing is the failure of the contemporary medical science community to come to consensus over the flood of evidence pointing to the presence of a bodywide energetic field generated by the cardiovascular system. The dominant systolic-centered model of heart function, which held sway for most of the $20^{\text {th }}$ century, was overturned in the late 1980s, nearly 35 years ago, and diastole is now widely recognized to be the primary determinant of cardiovascular function. And yet scientists continue to peddle their discredited molecular and cellular paradigm as if it were gospel.

By 1970, ten years after receiving the Nobel Prize, Macfarlane Burnet, eminent $20^{\text {th }}$ century immunologist, had soured on experimental medicine. In Genes, Dreams and Realities he argued that the contribution of laboratory science in unlocking the problem of disease had come to an end and that further research would amount to little more than filling in of details. Most of the breakthroughs in $20^{\text {th }}$ century medicine, he noted, were observational in nature and not based on experiment.

Burnet claimed that 'too much sensational material was being written about the future significance of discoveries in molecular biology.' He pointed to the increasing burden of chronic diseases and lack of meaningful change in their outcomes in the previous 3-4 decades. Modern science, he wrote, 'is by no means the triumphal march toward perpetual health and well-being' as popular accounts would suggest. And far from stunning breakthroughs he warned that molecular science 'might release some new and nasty problems on a world that already has more than it can cope with.' The SARS-CoV-2 pandemic has laid bare the failures of the experimental method and revealed the emperor to have no clothes.

In the second part of this series, we examine in greater detail the various strategies, including vaccination, that science-based societies have enacted during the pandemic to mitigate its influences. Cockburn's assertion that pandemic dynamics are unstoppable stands unchallenged.

\section{References}

1. Influenza: The Last Great Plague. W.I.B. Beveridge publ. Prodist New York. 1978

2. Unifying the epidemiological and evolutionary dynamics of pathogens. Grenfell BT, Pybus OG, Gog JR et al. Science. 2004; 303(5656): 327-32

3. Viral population dynamics and virulence thresholds. Lancaster KZ, Pfeiffer JK. Curr Opin Microbiol. 2012; 15(4): 525-30

4. Cell entry mechanisms of SARS-CoV-2. Shang J, 
Wan Y, Luo C et al. Proc Natl Acad Sci USA. 2020; 117(2):11727-34

5. The total number and mass of SARS-CoV-2 virions. Sender R, Bar-On YM, Gleizer S, et al. Proc Natl Acad Sci USA. 2021; 118(25): e2024815118

6. Cryo-EM structure of the 2019-nCoV spike in the prefusion conformation. Wrapp D, Wang N, Corbett KS et al. Science 2020; 367(6483): 1260-63

7. How did we get here? Short history of COVID-19 and other coronavirus-related epidemics. Lango MN Head Neck. 2020; 42(7): 1535-38

8. Continuing challenges in influenza. Webster RG, Govorkova EA, Ann NY. Acad Sci 2014; 1323:11539

9. Evaluating the massive underreporting and undertesting of COVID-19 cases in multiple global epicenters. Lau H, Khosrawipour T, Kocbach P, et al. Pulmonology 2021;27(2):110-15

10. Underreporting COVID-19: the curious case of the Indian subcontinent. Biswas RK, Afiaz A, Huq S. Epidemiol Infect. 2020; 148:e207

11. Covid-19 Mortality and underreporting in Brazil: analysis of data from government internet portals. Veiga E, Silva L, de Andrade Abi Harb MDP, Teixeira Barbosa Dos Santos AM, et al. J Med Internet Res. 2020; 22(8): e21413

12. Seroprevalence of immunoglobulin $M$ and $G$ antibodies against SARS-CoV-2 in China. Xu X, Sun J, Nie S, et al. Nat Med. 2020; 26(8): 1193-95

13. Population-based seroprevalence surveys of anti-SARS-CoV-2 antibody: an up-to-date review. Lai CC, Wang JH, Hsueh PR. J Infect Dis. 2020; 101:314-22

14. Seroprevalence of antibodies to SARS-CoV-2 in 10 sites in the United States, March 23-May 12, 2020. Havers FP, Reed C, Lim T, et al. JAMA Intern Med. 2020

15. Escape from neutralizing antibodies by SARS-CoV-2 spike protein variants. Weisblum Y, Schmidt F, Zhang F, et al. Elife. 2020 Oct 28;9:e61312

16. The spike of concern: the novel variants of SARS-
-CoV-2. Winger A, Caspari T. Viruses. 2021 May 27;13(6):1002.

17. SARS-CoV-2 entry related viral and host genetic variations: implications on COVID-19 severity, immune escape, and infectivity. Huang SW, Wang SF. Int J Mol Sci. 2021 Mar 17;22(6):3060.

18. Emerging SARS-CoV-2 variants of concern (VOCs): an impending global crisis. Thye AY, Law JW, Pusparajah P, et al. Biomedicines. 2021 Sep 23;9(10):1303

19. Biological significance of the genomic variation and structural dynamics of SARS-CoV-2 B.1.617. Fan LQ, Hu XY, Chen YY, et al. Front Microbiol $2021 ; 12: 750725$

20. Waning immunity to SARS-CoV-2: implications for vaccine booster strategies. Altmann DM, Boyton RJ. Lancet Resp Med 2021; 9(12):1356-58

21. Modeling the population effects of escape mutations in SARS-CoV-2 to guide vaccination strategies. Koopman JS, Simon CP, Getz WM, Salter R. Epidemics 2021; 36:100484

22. Waning antibody responses in COVID-19: what we can learn from the analysis of other coronaviruses. Hamady A, Lee J, Loboda ZA. Infection. 2021 Jul 29:1-15

23. Virus shedding dynamics in asymptomatic and mildly symptomatic patients infected with SARS-CoV-2. Li W, Su YY, Zhi SS, Huang J, et al. Clin Microbiol Infect. 2020; 26(11): 1556.e1-1556.e6

24. Differences of severe acute respiratory syndrome coronavirus 2 shedding duration in sputum and nasopharyngeal swab specimens among adult inpatients with coronavirus disease 2019. Wang K, Zhang X, Sun J et al. Chest 2020; 158(5): 1876-84

25. Prolonged persistence of SARS-CoV-2 in the upper respiratory tract of asymptomatic infected individuals. Saurabh S, Kumar R, Gupta MK, et al. QJM 2020; 113(8):556-80

26. Temporal dynamics in viral shedding and transmissibility of COVID-19. He X, Lau EHY, Wu P. Nat Med 2020; 26(5): 672-75

27. Omicron variant genome evolution and phyloge- 
netics. Kandeel M, Mohamed MEM, Abd El-Lateef HM, et al. J Med Virol. 2021 Dec

28. The significant immune escape of pseudotyped SARS-CoV-2 variant omicron. Zhang L, Li Q, Liang Z, et al. Emerg Microbes Infect. 2021:1-11

29. https:// www.washingtonpost.com/nation/2021/12/13/covid-omicron-variant-live-updates/

30. https://www.reuters.com/world/us/most-reported-us-omicron-cases-have-hit-fully-vaccinated-cdc-2021-12-10/

31. Disease mitigation measures in the control of pandemic influenza. Inglesby TV, Nuzzo JB, O'Toole T, et al. Biosecur Bioterror. 2006; 4(4):366-75

32. Risk factors for breakthrough SARS-CoV-2 infection in vaccinated healthcare workers. Alishaq $M$, Nafady-Hego H, Jeremijenko A, et al. PLoS One. 2021; 16(10):e0258820

33. Postvaccination SARS-CoV-2 infections among skilled nursing facility residents and staff members-Chicago, Illinois, December 2020-March 2021. Teran RA, Walblay KA, Shane EL, et al. MMWR 2021; 70(17):632-38

34. Association between vaccination with BNT162b2 and incidence of symptomatic and asymptomatic SARS-CoV-2 infections among health care workers. Angel Y, Spitzer A, Henig O, et al. JAMA 2021; 325(24):2457-65

35. Association of prior SARS-CoV-2 infection with risk of breakthrough infection following mRNA vaccination in Qatar. Abu-Raddad LJ, Chemaitelly H, Ayoub HH, et al. JAMA 2021; 326(19):1930-39

36. Results from a survey in healthy blood donors in South Eastern Italy indicate that we are far away from herd immunity to SARS-CoV-2. Fiore JR., Centra M, De Carlo A, et al. J Med Virol. 2021; 93(3): 173942

37. Leaky vaccines protect highly exposed recipients at a lower rate: implications for vaccine efficacy estimation and sieve analysis. Edlefsen PT. Comput Math Methods Med. 2014; 2014:813789

38. Imperfect Vaccination Can Enhance the Transmis- sion of Highly Virulent Pathogens. Read AF, Baigent SJ, Powers C. PLoS Biol. 2015; 13(7):e1002198

39. Vaccination and reduced cohort duration can drive virulence evolution: Marek's disease virus and industrialized agriculture. Atkins KE, Read AF, Savill NJ, et al. Evolution 2013; 67(3):851-60

40. Coronavirus disease 2019 (COVID-19) re-infection by a phylogenetically distinct severe acute respiratory syndrome coronavirus 2 strain confirmed by whole genome sequencing. To KK, Hung If, Ip JD, Chu AW, et al. Clin Infect Dis 2021; 73(9): e2946-51

41. Asymptomatic reinfection in 2 healthcare workers from India with genetically distinct severe acute respiratory syndrome coronavirus 2. Gupta V, Bhoyar RC, Jain A, et al. Clin Infect Dis 2021; 73(9): e2823-e2825

42. Symptomatic SARS-CoV-2 reinfection in a healthy healthcare worker in Italy confirmed by whole-genome sequencing. Loconsole D, Sallustio A, Accogli M, et al. Viruses 2021; 13(5): 899

43. A multicenter cohort study of indian centers on recurring SARS-CoV-2 infections in kidney transplant patients. Kute VB, Hegde U, Das P, Sharma A, et al. Exp Clin Transplant 2021; 19(10): 1023-31

44. Asymptomatic COVID-19 re-infection in a Japanese male by elevated half-maximal inhibitory concentration $\left(\mathrm{IC}_{50}\right)$ of neutralizing antibodies. Inada $M$, Ishikane $M$, Terada $M$, et al. Infect Chemother 2021; 27(7): 1063-67

45. Symptomatic severe acute respiratory syndrome coronavirus 2 reinfection of a healthcare worker in a Belgian nosocomial outbreak despite primary neutralizing antibody response. Selhorst $\mathrm{P}$, van Ierssel SH, Michiels J, et al. Clin Infect Dis 2021; 73(9);e2985-91

46. Genomic evidence for reinfection with SARS-CoV-2: a case study. Tillett RL, Sevinsky JR, Hartley PD, et al. Lancet Infect Dis 2021; 21(1): 52-58

47. SARS-CoV-2 Reinfection is a new challenge for the effectiveness of global vaccination campaign. Lo Muzio L, Ambosino M, Lo Muzio E, Quadri MFA. Int J Environ Res Pub Health 2021; 18(20): 11001 
48. Epidemiologic characteristics of cases with reinfection, recurrence, and hospital readmission due to COVID-19: a systematic review and meta-analysis. Sotoodeh Ghorbani S, Taherpour N, Bayat S, et al. J Med Virol 2022; 94(1); 44-53

49. Covid-19 Reinfection: Three Questions Scientists Are Asking. Ledford H. Nature 2020;585(7824):168-9.

50. Influenza: The Last Great Plague. W.I.B. Beveridge publ. Prodist New York 1978

51. WHO Coronavirus (COVID-19) Dashboard. https://covid19.who.int/

52. Household transmission of SARS-CoV-2: A systematic review and meta-analysis. Madewell ZJ, Yang Y, Longini IM, et al. JAMA Netw Open 2020; 3(12):e2031756

53. Contact settings and risk transmission in 3410 close contacts of patients with COVID-19 in Guangzhou, China: a prospective cohort study. Luo L, Liu D, Liao X, et al. Ann Intern Med 2020; 173(11): 879-887

54. SARS-CoV-2 seroprevalence and transmission factors among high-risk close contacts: A retrospective cohort study. Ng OT, Marimuthu K, Koh V, et al. Lancet Infect Dis 2021; 21(3):333-43

55. Preexisting and de novo humoral immunity to SARS-CoV-2 in humans. Ng KW, Faulkner N, Cornish GH, Rosa A. Science 2020; 370(6522): $1339-43$

56. Prevalence of underlying diseases in died cases of COVID-19: a systematic review and meta-analysis. Javanmardi F, Keshavarzi A, Akbari A, et al. PLoS One 2020; 15(10):e0241265

57. Coronavirus disease (COVID-19): A systematic review and meta-analysis to evaluate the impact of various comorbidities on serious events. Nandy K, Salunke A, Pathak SK, et al. Diabetes Metab Syndr 2020; 14(5):1017-25

58. Features of severe COVID-19: a systematic review and analysis. Del Sole F, Farcomeni A, Loffredo L, et al. Eur J Clin Invest 2020; 50(10):e13378

59. Effects of underlying comorbidities on the occur- rence of deaths in COVID-19 patients: A systematic review and meta-analysis. Khan MMA, Khan MN, Mustagir MG, et al. J Glob Health 2020; 10(2):020503

60. Gender Differences in Patients With COVID-19: Focus on Severity and Mortality. Jin JM, Bai P, He W, et al. Front Public Health 2020; 8: 152

61. Male sex identified by global COVID-19 metaanalysis as a risk factor for death and ITU admission. Peckham H, de Gruijter NM, Raine C, et al. Nat Commun 2020; 11(1): 6317

62. Sex differences in immune responses that underlie COVID-19 disease outcomes. Takahashi T, Ellingson MK, Wong P, et al. Nature 2020; 588(7837): 315-320

63. Prevalence of cardiovascular comorbidities in coronavirus disease 2019, severe acute respiratory syndrome, and middle eastern respiratory syndrome: pooled analysis of published data. Liu Y, Wu S, Qin M, et al. J Am Heart Assoc 2020; 9(17):e016812

64. Cardiovascular diseases burden in COVID-19: systematic review and meta-analysis. Hessami A, Shamshirian A, Heydari K, et al. Am J Emerg Med 2021; 46:382-91

65. Severity of COVID-19 and survival in patients with rheumatic and inflammatory disease: Data from the French RMD COVID-19 cohort of 694 patients.

66. FAI2R/SFR/SNFMI/SOFREMIP/CRI/IMIDIATE consortium and contributors. Ann Rheum Dis 2020; 80(4):527-38

67. High rates of 30-day mortality in patients with cirrhosis and COVID-19. Iavarone M, D'Ambrosio R, Soria A, et al. J Hepatol 2020; 73(5):1063-71

68. Clinical outcomes in hospitalized patients with COVID-19 and chronic inflammatory and autoimmune rheumatic diseases: a multicentric matched cohort study. Pablos JL, Galindo M, Carmona L, et al. Ann Rheum Dis 2020;79(12):1544-49

69. Thyroid disease is associated with severe coronavirus disease (2019) infection. Hariyanto TI, Kurniawan A. Diabetes Metab Syndr 2020; 14(5):1429-30 
70. Comorbidities and multi-organ injuries in the treatment of COVID-19. Wang T, Du Z, Zhu F, et al. Lancet 2020; 395(10228):e52

71. COVID-19 and diabetes: is there enough evidence? Tadic M, Cuspidi C, Sala C, et al. J Clin Hypertens (Greenwich) 2020; 22(6):943-48

72. Factors leading to high morbidity and mortality of COVID-19 patients with type 2 diabetes. Rajpal A, Rahimi L, Ismail-Beigi F. J Diabetes 12(12):895908

73. COVID-19 and diabetes: knowledge in progress. Hussain A, Bhowmik B, do Vale Moreira NC. Diabetes Clin Res Clin Pract 2020; 162:108142

74. COVID-19 pandemic, coronaviruses, and diabetes mellitus. Muniyappa R, Gubbi S. Am J Physiol Endocrinol Metab 2020;318(5):E736-41

75. Unexpected magnetic attraction: Evidence for an organized energy field in the human body. Thorp JA, Thorp KE, Lile EK, Viglione J. G Med Sci 2021; 2(4): 001-015.

76. Aether, fields \& energy dynamics in living bodies Part I. Thorp KE, Thorp JA, Walker PR. G Med Sci 2021; 2(5): 014-025.

77. Aether, fields \& energy dynamics in living bodies Part II. Thorp KE, Thorp JA, Walker PR. G Med Sci 2021; 2(6): 001-020.

78. Aether, fields \& energy dynamics in living bodies - Part III. Thorp KE, Thorp JA, Walker PR. G Med Sci 2021; 2(6): 021-047.

79. Negative intraventricular diastolic pressure in patients with mitral stenosis: evidence of left ventricular diastolic suction. Sabbah HN, Anbe DT, Stein PD. Am J Cardiol 1980; 45(3):pp 562-66.

80. Left ventricular diastolic suction as a mechanism of ventricular filling. Hori M, Yellin EL, Sonnenblick EH. Jpn Circ J 46(1): pp 124-129; 1982

81. The heart as a suction pump. Robinson TF, Factor SM, Sonnenblick EH Scientific American 254(6): pp 84-91; 1986

82. The heart is not a pump: a refutation of the pressu- re propulsion premise of heart function. Marinelli R, Fürst B, van der Zee H, McGinn H, Marinelli W. Frontier Perspectives 5(1): pp 15-24; Fall-Winter 1995

83. Spiral flow in laminar arteries? Stonebridge PA, Brophy CM. Lancet 338(8779): pp 1360-61; 1991

84. Spiral laminar flow in vivo. Stonebridge PA, Hoskins PR, Allan PL, Belck JF. Clin Sci (Lond) 91(1): pp 17-21; 1996

85. Helical and retrograde secondary flow patterns in the aortic arch studied by three-directional magnetic resonance velocity mapping. Kilner PJ, Yang GZ, Mohiaddin RH, Firmin DN, Longmore DB. Circulation 88(5): pp 2235-47; 1993

86. Physiological significance of helical flow in the arterial system and its potential clinical applications. Liu X, Sun A, Fan Y, Deng X. Ann Biomed Engineer 43(1): pp 3-15; 2015

87. Diastolic Dysfunction. Little WC, Cheng CP. Cardiol Rev 6(4): pp 231-239; 1988

88. State of the art: 'diastology' research 1998. Oki T. J Med Invest 45(1-4): pp 9-25; 1998

89. Evolving focus on diastolic dysfunction in patients with coronary artery disease. Ohara T, Little WC. Curr Opin Cardiol. 2010; 25(6): 613-21

90. Diastolic dysfunction in arterial hypertension. De Simone G, Palmieri V. J Clin Hypertens (Greenwich) $2001 ; 3(1): 22-27$

91. Diastolic dysfunction and hypertension. Nadruz W, Shah AM, Solomon SD. Med Clin North Am 2017; 101(1): 7-17

92. Effects of obesity on cardiovascular hemodynamics, cardiac morphology, and ventricular function. Alpert MA, Omran J, Bostick BP. Curr Obes Rep 2016; 5(4): 424-34

93. Obesity and metabolic features associated with long-term development of diastolic dysfunction in an initially healthy population-based cohort. Chau K, Girard N, Magnusson M, Lamiral Z, et al. Clin Res Cardiol 2018; 107(10): 887-896 
94. Left ventricular diastolic dysfunction in morbidly obese patients in the preoperative for bariatric surgery. Tavares IS, Sousa AC, Menezes Filho RS, et al. Arq Bras Cardiol 2012; 98(4): 300-06

95. Multimarker assessment of diastolic dysfunction in metabolic syndrome patients. Mocan M, Anton F, Suciu S, Rahaian R, et al. Metab Syndr Relat Disord 2017; 15(10): 507-514

96. Metabolic syndrome and cardiovascular diseases in Korea. Suh S, Lee MK J. Atheroscler Thromb 2014; 21(Suppl 1): S31-35

97. Left ventricular dysfunction in diabetes mellitus: an update. Freire CM, Moura AL, Barbosa Mde M, Machado LJ, et al. Arq Bras Endocrinol Metab 2007; 51(2): 168-75

98. Diastolic dysfunction in asymptomatic hemodialysis patients in the light of current echocardiographic guidelines. Malik J, Kudlicka J, Valerianova A, et al. J Cardiovasc Imaging 2019; 35(2): 313-17

99. Left ventricular diastolic dysfunction in early-stage chronic kidney disease. Otsuka T, Suzuki M, Yoshikawa H, Sugi K. J Cardiol 2009; 54(2): 199-204

100. Impaired systolic and diastolic left ventricular function in children with chronic kidney disease-results from the 4C study. Doyon A, Haas P, Erdem S, Ranchin B, et al. Sci Rep 2019; 9(1): 11462

101. Left ventricular diastolic dysfuction in diabetic patients: pathophysiology and therapeutic implications. Tsujino T, Kawasaki D, Masuyama T. Am J Cardiovasc Drugs 2006; 6(4): 219-30

102. Association between non-alcoholic fatty liver disease and left ventricular diastolic dysfunction in patients of type 2 diabetes. Saluja M, Kumar K, Swami YK, Meena SR. J Assoc Physicians India 2019; 67(8):20-24

103. Evolving focus on diastolic dysfunction in patients with coronary artery disease. Ohara T, Little WC. Curr Opin Cardiol 2010; 25(6):613-21

104. Prognostic implications of diastolic dysfunction change in patients with coronary artery disease undergoing percutaneous coronary intervention.
Kim EK, Hahn JY, Park TK, et al. Circ J 2019; 83(9):1891-1900

105. Diastolic function in coronary artery disease. Carroll JD, Carroll EP. Herz 1991; 16(1):1-12

106. Diastolic heart failure in the elderly. Kitzman DW. Heart Fail Rev 2002; 7(1):17-27

107. Diastolic heart failure: definitions and terminology. Zile MR, Baicu CF, Bonnema DD. Prog Cardiovasc Dis 2005; 47(5):307-13

108. Left ventricular diastolic function in the elderly. Tokushima T, Reid CL, Gardin JM. J Geriatr Cardiol 2001; 10(1):20-29

109. Diastolic heart failure: a difficult problem in the elderly. Banerjee P, Clark AL, Cleland JG. Am J Geriatr Cardiol 2004; 13(1):16-21

110. Early echocardiographic detection of left ventricular diastolic dysfunction in patients with systemic lupus erythematosus asymptomatic for cardiovascular disease. Leone P, Cicco S, Prete M, et al. Clin Exp Med 2020; 20(1):11-19

111. Diastolic dysfunction and endothelial dysfunction is systemic lupus erythematosus. Yildiz A, Soydinc S. Rheumatol Int 2015; 35(7):1281-82

112. Diastolic dysfunction in rheumatoid arthritis: a meta-analysis and systematic review. Aslam F, Bandeali SJ, Khan NA, et al. Arthritis Care Res (Hoboken) 2013; 65(4):534-43

113. Prevalence of systolic and diastolic dysfunction inpatients with type I diabetes without known heart disease: the thousand \& 1 study. Jensen MT, Sogaard P, Andersen HU, et al. Diabetologia 2014; 57(4):672-80

114. Endothelial dysfunction in early systemic lupus erythematosus patients and controls without previous cardiovascular events. Taraborelli M, Sciatti E, Bonadei I, et al. Arthritis Care Res (Hoboken) 2018;70(9):1277-1283

115. A History of Immunology. Arthur M. Silverstein. Academic Press 1989; pp. 59-123

116. Species and Specificity: An Interpretation of the 
History of Immunology. Pauline Mazumdar publ. Cambridge Univ Press 1995: pp. 179-253

117. Glycobiology of the cell surface: Its debt to cell electrophoresis 1940-65. Cook GMW. Electrophoresis 2016; 37(11): 1399-1406

118. Antibody structure. Stanfield RL, Wilson IA. Microbiol Spectr 2014; 2(2):2.2.06

119. The hinge region of therapeutic antibodies: major importance of a short sequence. Deveuve Q, Gouilleux-Gruart V, Thibault G et al. Med Sci (Paris) 2019; 35(12): 1098-1105

120. Structural dynamics of SARS-CoV-2 variants: A health monitoring strategy for anticipating Covid-19 outbreaks. Fantini J, Yahi N, Azzaz F, Chahinian H. J Infection 83 (2021) 197-206

121. Structural insights into the mechanisms of antibody-mediated neutralization of flavivirus infection: implications for vaccine development. Pierson TC, Fremont DH, Kuhn RJ, Diamond MS. Cell Host Microbe 2008; 4(3):229-38

122. B-cell receptor: from resting state to activate. Treanor B. Immunol 2012;136(1):21-7

123. Structure of an HIV gp120 envelope glycoprotein in complex with the CD4 receptor and a neutralizing human antibody. Kwong PD, Wyatt R, Robinson J, et al. Nature 1998; 393(6686):648-59

124. Conformational change in herpes simplex virus entry glycoproteins detected by dot blot. Sari TK, Gianopulos KA, Nicola AV Methods Mol Biol 2020;2060:319-26

125. Ligand-induced conformational change in T-cell receptor associated with productive immune synapses. Risueño RM, Gil D, Fernández E, Sánchez-Madrid F et al Blood 2005; 106(2):601-08

126. Antibody-induced conformational changes in herpes simplex virus glycoprotein $\mathrm{qD}$ reveal new targets for virus neutralization. Lazear E, Whitbeck JC, Ponce-de-Leon M, et al. Virology 2012; 86(3):1563-76

127. Antibody-receptor interactions mediate antibody-dependent cellular cytotoxicity. Sun Y, Izadi S, Callahan M, et al.J Biol Chem 2021;297(1):100826
128. Conformational changes in the antibody constant domains upon hapten-binding. Sun Y, Izadi S, Callahan M, et al. Immunol 2005; 42(1):9-18

129. Dynamically driven protein allostery. Popovych N, Shangjin Sun S, et al. Nat Struct Mol Biol 2006; 13(9): 831-838.

130. The changing landscape of protein allostery. Swain JF, Gierasch LM. Curr Opin Struct Biol 2006; 16(1): 102-08

131. Dynamic activation of protein function: a view emerging from NMR spectroscopy. Wand AJ Nat Struct Biol 2001; 8(11):926-31

132. Protein dynamics and allostery: an NMR view. Tzeng SR, Kalodimos CG. Curr Opin Struct Biol 2011; 21(1): 62-67

133. Is allostery an intrinsic property of all dynamic proteins? Gunasekaran K, Ma B, Nussinov R. Proteins 2004; 57(3): 433-43

134. Hydrogen bond networks determine emergent mechanical and thermodynamic properties across a protein family. Livesay DR, Huynh DH, Dallakyan S, et al. hem Cent J 2008; 2:17

135. Ensemble properties of network rigidity reveal allosteric mechanisms. Livesay DR, Huynh DH, Dallakyan S, et al. Methods Mol Biol 2012; 796:279-304

136. Antigen binding allosterically promotes Fc receptor recognition. Zhao J, Nussinov R, Ma B. MAbs 2019; 11(1):58-74

137. Local and Global Anatomy of Antibody-Protein Antigen Recognition Wang M, Zhu D, Zhu J, et al. J Mol 2018: 31(5):e2693

138. Antigen physicochemical properties allosterically effect the IgG Fc-region and Fc neonatal receptor affinity. Sun Y, Estevez A, Schlothauer T, et al. MAbs 2020; 12(1):1802135

139. Origins of specificity and affinity in antibody-protein interactions. Peng H-P, Lee KH, Jian J-H, Yang A-S. Proc Natl Acad Sci USA 2014; 111(26); e2656-651

140. How Does Nature Harness Thermodynamic Fluc- 
tuations for Life? The Diverse Functional Roles of Conformational Ensembles in the Cell. Wei G, Xi W, Nussinov R, Ma B Chem Rev 2016; 116(11): 6516-51

141. Multiple conformational selection and induced fit events take place in allosteric propagation. Nussinov R, Ma B, Tsai C-J. Biophys Chem 2014; 186:22-30

142. Protein-protein interaction networks: how can a hub protein bind so many different partners? Tsai CJ, Ma B, Nussinov R. Trends Biochem Sci 2009; 34(12): 594-600

143. Multiple diverse ligands binding at a single protein site: a matter of pre-existing populations. $\mathrm{Ma}$ B, Shatsky M, Wolfson HJ, Nussinov R. Protein Sci 2002; 11(2): 184-97

144. Dynamic profiling of binding and allosteric propensities of the SARS-CoV-2 spike protein with different classes of antibodies: mutational and perturbation-based scanning reveals the allosteric duality of functionally adaptable hotspots. Verkhivker G, Agajanian S, Oztas D, et al. Chem Theory Comput 2021; 17(7):4578-98

145. Principles of protein-protein interactions: what are the preferred ways for proteins to interact? Keskin O, Gursoy A, Ma B, Nussinov R. Chem Rev 108(4): 1225-44

146. Protein function and allostery: a dynamic relationship. Kaladimos CG. NY Acad Sci 2012; 1260:81-86

147. Protein dynamics and allostery: an NMR view. Tzeng SR, Kalodimos CG. Curr Opin Struct Biol 2011; 21(1):62-67

148. Dynamically driven protein allostery. Popovych $\mathrm{N}$, Sun S, Ebright RH, et al. Nat Struct Mol Biol 2006; 13(9):831-38

149. Dynamic activation of an allosteric regulatory protein. Tzeng SR, Kalodimos CG. Nature 2009; 462(7271):368-72

150. Dynamic network modeling of allosteric interactions and communication pathways in the SARS-CoV-2 spike trimer mutants: Differential modulation of conformational landscapes and signal transmission via cascades of regulatory switches. Verkhivker GM, Di Paola L. J Phys Chem B 2021; 125(3):850-73

151. Mutations in antibody fragments modulate allosteric response via hydrogen-bond network fluctuations. Srivastava A, Tracka MB, Uddin S, et al. Biophys J 2016; 110(9):1933-42

152. Evidence of escape of SARS-CoV-2 variant B.1.351 from natural and vaccine-induced sera. Zhou D, Dejnirattisai W, Supasa P, et al. Cell 2021; $184: 2348-61$ e2346.

153. The Spike D614G mutation increases SARS-CoV-2 infection of multiple human cell types. Daniloski Z, Jordan TX , Ilmain JK, et al. Elife 2021; 10 :e65365

154. SARS-CoV-2 one year on: evidence for ongoing viral adaptation. Peacock TP, Penrice-Randal R, Hiscox JA, Barclay WS. J Gen Virol 2021; 102

155. Escape from neutralizing antibodies by SARS-CoV-2 spike protein variants. Weisblum Y, Schmidt F, Zhang F. eLife 2020; 9:e61312

156. Recurrent deletions in the SARS-CoV-2 spike glycoprotein drive antibody escape. McCarthy KR, Rennick LJ, Nambulli S, et al. Science 2021; 371: 1139-1142.

157. Antigen-induced allosteric changes in a human IgG1 Fc increase low-affinity Fcgamma receptor binding. Orlandi C, Deredge D, Ray K, et al. Structure 2020; 28(5):516-27.e5

158. Antibody-dependent enhancement of coronavirus. Wen J, Cheng Y, Ling R, et al. Int J Infect Dis 100 (2020) 483-489

159. Antibody-Dependent Enhancement of SARS-CoV-2 Infection Is Mediated by the IgG Receptors Fc $\gamma$ RIIA and Fc $\gamma$ RIIIA but Does Not Contribute to Aberrant Cytokine Production by Macrophages. Maemura T, Kuroda M, Armbrust T, et al. mBio 2021; 12(5):e0198721

160. Fc receptors in antibody-dependent enhancement of viral infections. Taylor A, Foo SS, Bruzzone R, et al. Immunol Rev 2015; 268(1): 340-64

161. Molecular mechanisms for antibody-dependent 
enhancement of coronavirus entry. Wan Y, Shang J, Sun S, et al. J Virol 2020; 94(5):e02015-19

162. A perspective on potential antibody-dependent enhancement of SARS-CoV-2. Arvin AM, Fink K, Schmid MA, et al. Nature 2020:584(7821):35363

163. The role of IgG Fc receptors in antibody-dependent enhancement. Bournazos S, Gupta A, Ravetch JV, et al. Nat Rev Immunol 2020; 20(10):63343

164. Is antibody-dependent enhancement playing a role in COVID-19 pathogenesis? Negro F. Swiss Med Wkly 2020; 150:1

165. Implications of antibody-dependent enhancement of infection for SARS-CoV-2 countermeasures. Eroshenko N, Gill T, Keaveney K, et al. Nat Biotechnol 2020; 38(7):788-9

166. COVID-19 vaccines: should we fear ADE? Halstead SB, Katzelnick L. J Infect Dis 2020; 222(12):1946-50

167. Protein misfolding disease. Hartl FU. Annu Rev Biochem 2017; 86:21-26

168. Structure and dynamics of intrinsically disordered proteins. Fu B, Vendruscolo M. Adv Exp Med Biol 2015; 870:35-48

169. Water structure and interactions with protein surfaces. Raschke TM. Curr Opin Struct Biol 2006 Apr;16(2):152-9

170. Water Determines the Structure and Dynamics of Proteins. Bellissent-Funel MC, Hassanali A, Havenith $\mathrm{M}$, Henchman $\mathrm{R}$, Pohl $\mathrm{P}$, Sterpone F, van der Spoel D, Xu Y, Garcia AE. Chem Rev 2016 Jul 13;116(13):7673-97

171. Water mediation in protein folding and molecular recognition. Levy Y, Onuchic JN. Annu Rev Biophys Biomol Struct 2006;35:389-415.

172. Dynamics of hydration water in proteins. Teixeira J. Gen Physiol Biophys 2009;28(2):168-73.

173. Sub-terahertz spectroscopy reveals that proteins influence the properties of water at greater distances than previously detected. Sushko O, Du- brovka R, Donnan RS. J Chem Phys 2015 Feb 7;142(5):055101

174. The role of water in amyloid aggregation kinetics. Stephens AD, Kaminski Schierle GS. Curr Opin Struct Biol 2019 Oct; 58:115-123

175. Local structure and dynamics of hydration water in intrinsically disordered proteins. Rani P, Biswas P. J Phys Chem B 2015 Aug; 119(34): 10858-67

176. Interaction with surrounding water plays a key role in determining the aggregation propensity of proteins. Chong SH, Ham S Angew. Chem Int Ed Engl 2014 Apr: 53(15):1961-4

177. Protein structural and surface water rearrangement constitute major events in the earliest aggregation stages of tau. Pavlova A, Cheng CY, Kinnebrew M, Lew J, Dahlquist FW, Han S. Proc Natl Sci USA 2016 Jan; 113(2):E127-36

178. Role of water in aggregation and amyloid polymorphism. Thirumalai D, Reddy G, Straub JE. Acc Chem Res 2012 Jan; 45(1):83-92

179. The Fourth Phase of Water: Beyond Solid, Liquid, Vapor Gerald H. Pollack Ebner \& Sons Publishers, 2013

180. Cells, Gels and the Engines of Life: A New Unifying Approach to Cell Function Gerald H. Pollack publ. Ebner \& Sons, Seattle WA, 2001

181. Water and the Cell eds. Gerald H. Pollack, Ivan L. Cameron, Denys N. Wheatley publ. Springer 2006; pg. 12

182. Life at the Cell and Below-Cell Level: The Hidden History of a Fundamental Revolution in Biology Gilbert Ling Pacific Press, New York (2001)

183. A Physical Theory of the Living State: The Association-Induction Hypothesis. Ling GN. Waltham MA: Blaisdell; 1962

184. Antibody responses in COVID-19: a review. Chvatal-Medina M, Mendez-Cortina Y, Patiño PJ, et al. Front Immunol 2021; 12:633184

185. Antibody tests for identification of current and past infection with SARS CoV-2. Deeks JJ, Dinnes J, Takwoingi Y, et al. Cochrane Database Syst Rev 
2020;6(6): CDo13652

186. Population-based seroprevalence surveys of anti-SARS-CoV-2 antibody: an up-to-date review. Lai CC, Wang JH, Hsueh PR. J Infect Dis 2020;101:314-22

187. Convergent antibody responses to SARS-CoV-2 in convalescent individuals. Robbiani DF, Gaebler C, Muecksch F, et al. Nature 2020; 584(7821):43742

188. Longitudinal observation and decline of neutralizing antibody responses in the three months following SARS-CoV-2 infection in humans. Seow J, Graham C, Merrick B, et al. Nat Microbiol 2020; 5(12): 1598-1607

189. Kinetics of viral load and antibody response in relation to COVID-19 severity. Wang Y, Zhang L, Sang L, et al. J Clin Invest 2020; 130(10):5235-44

190. Antibody kinetics in primary- and secondary-care physicians with mild to moderate SARS-CoV-2 infection. Orth-Höller D, Eigentler A, Weseslindtner L, Möst J. Emerg Microbes Infect 2020; 9(1):1-12

191. Humoral Immune Response to SARS-CoV-2 in Iceland. Gudbjartsson DF, Norddahl GL, Melsted P, et al. NEJM 2020; 383(18): 1724-34

192. Robust neutralizing antibodies to SARS-CoV-2 infection persist for months. Wajnberg A, Amanat F, Firpo A, et al. 2020; 370(6521): 1227-30

193. Antibody tests have higher sensitivity at 15 days after symptom onset and $99 \%$ specificity for detecting SARS-CoV-2. Lawandi A, Danner RL. Intern Med 2020; 173(10): JC57

194. Evolution of antibody immunity to SARS-CoV-2. Gaebler C, Wang Z, Lorenzi JCC, et al. Nature 2021; 591(7851): 639-44.

195. Predictors of nonseroconversion after SARS-CoV-2 infection. Liu W, Russell RM, Bibollet-Ruche F, et al. Emerg Infect Dis 2021; 27(9): 2454-2458

196. Multi-center nationwide comparison of seven serology assays reveals a SARS-CoV-2 non-respon- ding seronegative subpopulation. Oved K, Olmer L, Shemer-Avni Y, et al. E Clinical Medicine 2020; 29:100651.

197. SARS-CoV-2 seroconversion and viral clearance in patients hospitalized with COVID-19: viral load predicts antibody response. Masia M, Telenti G, Fernandez M, et al. Open Forum Infect Dis 2021; 8(2): ofab005

198. Longitudinal Serology of SARS-CoV-2-Infected Individuals in India: A Prospective Cohort Study. Thiruvengadam R, Chattopadhyay S, Mehdi F, et al. Am J Trop Med Hyg 2021;105(1):66-72

199. SARS-CoV-2 seroconversion and viral clearance in patients hospitalized with COVID-19: viral load predicts antibody response. Masia M, Telenti G, Fernandez M, et al. Open Forum Infect Dis 2021: 8(2): ofab005

200. SARS-CoV-2-IgG response is different in COVID-19 outpatients and asymptomatic contact persons. Wellinghausen N, Plonné D, Voss M, et al. J Clin Virol 2020; 130: 104542

201. Convalescent Plasma Antibody Levels and the Risk of Death from Covid-19. Joyner MJ, Carter RE, Senefeld JW, et al. NEJM 2021; 384(11):1-13

202. Differences in Antibody Kinetics and Functionality Between Severe and Mild Severe Acute Respiratory Syndrome Coronavirus 2 Infections. Rijkers G, Murk JL, Wintermans B, van Looy B, et al. J Infect Dis 2020; 222(8):1265-9.

203. Antibody responses to SARS-CoV-2 in patients with differing severities of coronavirus disease 2019. Kowitdamrong E, Puthanakit T, Jantarabenjakul W, et al. PLoS One 2020; 15(10): e0240502

204. Quantifying antibody kinetics and RNA detection during early-phase SARSCoV-2 infection by time since symptom onset. Borremans B, Gamble A, Prager KC, et al. Elife 2020; 9:1-27

205. A systematic review of antibody mediated immunity to coronaviruses: kinetics, correlates of protection, and association with severity. Huang AT, Garcia-Carreras B, Hitchings MDT, et al. Nat Commun 2020; 11(1):1-16 
206. Kinetics of Severe Acute Respiratory Syndrome Coronavirus 2 (SARS-CoV-2) Antibody Avidity Maturation and Association with Disease Severity. Luo YR, Chakraborty I, Yun C, et al. Clin Infect Dis 2021; 73(9): e3095-97

207. The kinetics of humoral response and its relationship with the disease severity in COVID-19. Ren L, Zhang L, Chang D, et al. Commun Biol 2020; 3(1):1-7

208. A longitudinal study of SARS-CoV-2 infected patients reveals a high correlation between neutralizing antibodies and COVID-19 severity. Legros V, Denolly S, Vogrig M, et al. Cell Mol Immunol 2021; 18(2): 318-27

209. Cross-reactive antibody against human coronavirus OC43 spike protein correlates with disease severity in COVID-19 patients: a retrospective study. Guo L, Wang Y, Kang L, Hu Y, et al. Emerg Microbes Infect 2021; 10(1): 664-76

210. Humoral immune responses and neutralizing antibodies against SARS-CoV-2: implications in pathogenesis and protective immunity. Carrillo J, Izquierdo-Useros N, Ávila-Nieto C, et al. Biochem Biophys Res Commun 2021; 538: 187-91

211. Delayed production of neutralizing antibodies correlates with fatal COVID-19. Lucas C, Klein J, Sundaram ME, et al. Nat Med 2021; 27(7): 117886

212. A longitudinal study of SARS-CoV-2-infected patients reveals a high correlation between neutralizing antibodies and COVID-19 severity. Legros V, Denolly S, Vogrig M, et al. Cell Mol Immunol 2021; 18(2): 318-27

213. SARS-CoV-2 Infection severity is linked to superior humoral immunity against the spike. Guthmiller JJ, Stovicek O, Wang J, et al. mBio 2021; 12(1): e02940-20

214. Magnitude and Kinetics of Anti-Severe Acute Respiratory Syndrome Coronavirus 2 Antibody Responses and Their Relationship to Disease Severity. Lynch KL, Whitman JD, Lacanienta NP, et al. Clin Infect Dis 2021; 72(2): 301-08

215. The dynamics of immune response in COVID-19 patients with different illness severity. Zhang B, Yue D, Wang Y, et al. J Med Virol 2020 July):1-8.

216. The kinetics of viral load and antibodies to SARS-CoV-2. Sun J, Tang X, Bai R, et al. Clin Microbiol Infect 2020;26(12):1-16

217. Immune responses to SARS-CoV-2 infection in hospitalized pediatric and adult patients. Pierce CA, Preston-Hurlburt P, Dai Y et al Sci Transl Med 2020; 12(564): eabd5487

218. Disease severity dictates SARS-CoV-2-specific neutralizing antibody responses in COVID-19. Chen X, Pan Z, Yue S, et al. Signal Transduct Target Ther 2020; 5(1):1-6.

219. Antibody Responses in COVID-19: A Review Chvatal-Medina M, Mendez-Cortina Y, Pablo J. Patiño PJ, et al. Front Immunol 2021; 12:633184

220. High neutralizing antibody titer in intensive care unit patients with COVID-19. Liu L, To KKW, Chan KH, et al. Emerg Microbes Infect 2020; $9(1): 1-30$

221. Anti-SARS-CoV-2 Antibody Responses in Convalescent Plasma Donors Are Increased in Hospitalized Patients; Subanalyses of a Phase 2 Clinical Study. Microorganisms. Terpos E, Politou M, Sergentanis TN, et al. Microorg 2020; 8(12): 1885

222. Sex, age, and hospitalization drive antibody responses in a COVID-19 convalescent plasma donor population. Klein SL, Pekosz A, Park HS, et al. J Clin Invest 2020; 130(11):6141-50

223. Postconvalescent SARS-CoV-2 IgG and neutralizing antibodies are elevated in individuals with poor metabolic health. Racine-Brzostek SE, Yang HS, Jack GA, et al. J Clin Endocrinol Metab 2021; 106(5): e2025-e2034

224. The Birth of Immunology: Metchnikoff, the embryologist. Chernyak L, Tauber AI. Cell Immunol 1988; 117: 218-233

225. The Birth of Immunology II: Metchnikoff and his critics. Tauber AI, Chernyak L. Cell Immunol 1989; 121: 447-473

226. The Birth of Immunology III: The Fate of Pha- 
gocytosis Theory. Tauber AI. Cell Immunol 1992; 139: $505-530$

227. Role of innate and adaptive immune mechanisms in cardiac injury and repair. Epelman S, Liu PP, Mann DL. Nat Rev Immunol 2015 Feb;15(2):11729.

228. Neutrophil migration in infection and wound repair: going forward in reverse. De Oliveira $S$, Rosowski EE, Huttenlocher A. Nat Rev Immunol 2016 May 27;16(6):378-91.

229. Regulation of macrophage development and function in peripheral tissues. Lavin Y, Mortha A, Rahman A, Merad M. Nat Rev Immunol 2015 Dec;15(12):731-44.

230. Fetal monocytes and the origins of tissue-resident macrophages. Hoeffel G, Ginhoux F Cell Immunol 2018 Aug;330:5-15.

231. Macrophage defense mechanisms against intracellular bacteria. Weiss G, Schaible UE Immunol Rev 2015 Mar;264(1):182-203

232. Protective and pathogenic functions of macrophage subsets. Murray PJ, Wynn TA. Nat Rev Immunol 2011 Oct 14;11(11):723-37.

233. Adaptive innate immunity or innate adaptive immunity? Černy J, Striž I. Clin Sci (Lond) 2019 Jul 17;133(14):1549-1565.

234. Trained immunity: a memory for host defense. Netea MG, Quintin J, van der Meer JW. Cell Host Microbe. 2011 May 19;9(5):355-61

235. Trained immunity: A program of innate immune memory in health and disease. Netea MG, Joosten LAB, Latz E, Mills KHG, et al. Science 2016 Apr 22;352(6284):aaf1098.

236. Immune balance: the development of the idea and its applications. Swiatczak B. J Hist Biol Fall 2014;47(3):411-42.

237. Epigenetic Regulation of Monocyte and Macrophage Function. Hoeksema MA, de Winther MPJ Antioxid Redox Signal 2016 Nov 10;25(14):758774.

238. Human monocyte-to-macrophage differentiation involves highly localized gain and loss of DNA methylation at transcription factor binding sites. Dekkers KF, Neele AE, Jukema JW, Heiimans BT, et al. Epigenetics Chromatin 2019 Jun 6;12(1):34.

239. Dynamic epigenetic enhancer signatures reveal key transcription factors associated with monocytic differentiation states. Pham T-H, Benner C, Lichtinger M, Schwartzfischer L, et al. Blood 2012 Jun 14;119(24):e161-71.

240. Transcriptional control of monocyte and macrophage development. Kurotaki D, Sasaki H, Tamura T. Int Immunol 2017 Mar 1;29(3):97-107.

241. Macrophage plasticity, polarization, and function in health and disease. Shapouri-Moghaddam A, Mohammadian S, Vazini H, Taghadosi M, et al. J Cell Physiol 2018 Sep;233(9):6425-6440.

242. Role of Human Macrophage Polarization in Inflammation during Infectious Diseases. Atri C, Guerfali FZ, Laouinin D. Int J Mol Sci 2018 Jun 19;19(6):1801.

243. Diversity, Mechanisms, and Significance of Macrophage Plasticity. Locati M, Curtale G, Mantovani A. Annu Rev Pathol 2020 Jan 24;15:123-147.

244. T Helper Cell Differentiation, Heterogeneity, and Plasticity. Zhu J. Cold Spring Harb Perspect Biol 2018 Oct 1;10(10):a030338.

245. T-cell subsets (Th1 versus Th2). Romagnani S. Cold Spring Harb Perspect Biol 2018 Oct 1;10(10):a030338.

246. Th1/Th2 balance: the hypothesis, its limitations, and implications for health and disease. Kidd $\mathrm{P}$ Altern Med Rev 2003 Aug;8(3):223-46.

247. Functions of lysosomes. De Duve C, Wattiaux R Annu Rev Physiol 1966; 28:435-492.

248. The lysosome turns fifty. De Duve C Nat Cell Biol 2005; 7:847-849

249. Historical landmarks of autophagy research. Ohsumi Y. Cell Res 2014 Jan;24(1):9-23.

250. Autophagy and energy metabolism. Yang J, Zhou R, Ma Z. Adv Exp Med Biol 2019;1206:329-357 
251. Autophagy and the immune system, Kuballa P, Nolte WM, Castoreno AB, Xavier RJ. Annu Rev Immunol 2012;30:611-46

252. Autophagy in innate and adaptive immunity. Xu Y, Eissa NT. Proc Am Thorac Soc 2010;7(1):22-28

253. Autophagy in immunity and inflammation. Levine B, Mizushima N, Virgin HW. Nature 2011;469(7330):323-35.

254. Autophagy and inflammation. Matsuzawa-Ishimoto Y, Hwang S, Cadwell K. Annu Rev Immunol 2018;36:73-101

255. Autophagy and inflammation in ischemic stroke. Mo Y, Sun YY, Liu KY. Neural Regen Res 2020;15(8):1388-1396

256. Autophagy and inflammation regulation in acute kidney injury. Gong L, Pan Q, Yang N Front Physiol 2020;11:576463

257. Autophagy and kidney inflammation. Kimura T, Isaka Y, Yoshimori T. Autophagy 2017;13(6):9971003

258. Autophagy: the spotlight for cellular stress response. Ravanan P, Srikumar IF, Talwar P. Life Sci 2017;188:53-67

259. Autophagy in chronic kidney diseases. Lin TA, Wu VC, Wang CY. Cells 2019; 8(1): 61

260. Autophagy in diabetic neuropathy. Ding Y, Choi ME. J Endocrinol 2015; 224(1): R15-30

261. Disorders of lysosomal acidification: the emerging role of v-ATPase in aging and neurodegenerative disease. Colacurcio DJ, Nixon RA. Ageing Res Rev 2016: 32: 75-88

262. The emerging roles of vacuolar-type ATPase-dependent lysosomal acidification in neurodegenerative diseases. Song Q, Meng B, Xu H, Mao Z. Transl Neurodegen 2020; 9(1): 17

263. Highlights in the fight against COVID-19: does autophagy play a role in SARS-CoV-2 infection? Delorme-Axford E, Klionsky DJ. Autophagy 2020; 16(12):2123-27

264. Autophagy as an emerging target for COVID-19: lessons from an old friend, chloroquine. Bonam SR, Muller S, Bayry J, Klionsky DJ. Autophagy 2020; 16(12):2260-66

265. Autophagy: the potential link between SARS-CoV-2 and cancer. Habibzadeh P, Dastsooz $\mathrm{H}$, Eshraghi M, et al. Cancers (Basel) $2021 \mathrm{Nov}$ 16;13(22):5721.

266. Taming the Autophagy as a Strategy for Treating COVID-19. Garcia-Pérez BE, González-Rojas JA, Salazar MA. Cells 2020; 9(12):2267-70

267. Open questions for harnessing autophagy-modulating drugs in the SARS-CoV-2 war: hope or hype? Brest P, Benzaquen J, Klionsky DJ, Hofman P, et al. Autophagy. 2020 Dec;16(12):2267-2270

268. Altered bioenergetics and mitochondrial dysfunction in monocytes in patients with Covid-19 pneumonia. Gibellini L, De Biasi S, Paolini A, Borella R, et al. EMBO Mol Med 2020; 12(12): e13001

269. Coronavirus (Covid-19) sepsis: revisiting mitochondrial dysfunction in pathogenesis, aging, inflammation and mortality. Shenoy S. Inflamm Res 2020;69(11):1077-1085

270. Pathogenic mitochondrial dysfunction and metabolic abnormalities. Moos WH, Faller DV, Glavas IP, et al. Biochem Pharmacol 2021;193:114809

271. Mitochondrial dysfunction as a trigger of innate immune responses and inflammation. West AP. Toxicology 2017; 391: 54-63

272. Mitochondrial dysfunction and damage associated molecular patterns (DAMPS) in chronic inflammatory diseases. Dela Cruz CS, Kang MJ. Mitochondrion 2018; 41: 37-44

273. Mitochondria and inflammation. Kolmychkova KI, Zhelankin AV, Karagodin VP, Orekhov AN. Patol Fiziol Eksp Ter 2016;60(4):114-21

274. Mitochondria and the autophagy-inflammation-cell death axis in organismal aging. Green DR, Galluzzi L, Kroemer G. Science 2011;333(6046):1109-12

275. Mitochondria and the link between neuroinflammation and neurodegeneration. Di Filippo $M$, 
Chiasserini D, Tozzi A, et al. J Alzheimers Dis 2010;20 Suppl 2: S369-79

276. Inflammation and mitochondrial dysfunction: a vicious circle in neurodegenerative disorders? van Horssen J, van Schaik P, Witte M. Neurosci Lett 2019;710:132931

277. Mitochondrial dysfunction in pathophysiology of heart failure. Zhou B, Tian R.J. Clin Invest 2018;128(9):3716-3726

278. The interplay between inflammation, oxidative stress, DNA damage, DNA repair and mitochondrial dysfunction in depression. Czarny $\mathrm{P}$, Wigner P, Galecki P, Sliwinski T. Prog Neuropsychopharmacol Biol Psychiatry 2018;80(Pt C):309-321

279. Mitochondrial dysfunction in obesity. de Mello $\mathrm{AH}$, Costa AB, Engel JDG, Rezin GT. Life Sci 2018;192:26-32

280. Mitochondrial Dysfunction and Multiple Sclerosis. Peixoto de Barcelos I, Troxell RM, Graves JS. Biology (Basel) 2019 May 11;8(2):37

281. Assessment of mitochondrial dysfunction in lymphocytes of patients with systemic lupus erythematosus. Perl A, Hanczko, Doherty E. Methods Mol Biol 2012;900:61-89

282. Mitochondrial dysfunction in rheumatoid arthritis: A comprehensive analysis by integrating gene expression, protein-protein interactions and gene ontology data. Panga V, Kallor AA, Nair A, Harshan S, Raghunathan S. PLoS One 2019 Nov 8;14(11):e0224632

283. Hypoxia, mitochondrial dysfunction and synovial invasiveness in rheumatoid arthritis. Fearon U, Canavan M, Biniecka M, Veale DJ. Nat Rev Rheumatol 2016 Jul;12(7):385-97

284. Mitochondrial dysfunction in diabetes: from molecular mechanisms to functional significance and therapeutic opportunities. Sivitz WI, Yorek MA. Antioxid Redox Signal 2010;12(4):537-77

285. Mitochondrial impairment drives intestinal stem cell transition into dysfunctional Paneth cells predicting Crohn's disease recurrence. Khaloian S, Rath E, Hammoudi N, Gleisinger E, et al. Gut
2020 Nov;69(11):1939-1951

286. Mitochondrial dysfunction, persistent oxidative damage, and catalase inhibition in immune cells of naïve and treated Crohn's disease. Beltrán B, Nos P, Dasi F, Iborra M, et al. Inflamm Bowel Dis 2010 Jan;16(1):76-86

287. Autophagy mediates neutrophil responses to bacterial infection. Chargui A, El May MV APMIS 2014 Nov;122(11):1047-58.

288. Autophagy in innate immunity against intracellular bacteria. Amano A, Nakagawa I, Yoshimori T. J Biochem 2006 Aug;140(2):161-6.

289. Autophagy in immunity and cell-autonomous defense against intracellular microbes. Deretic V. Immunol Rev 2011 Mar;240(1):92-104.

290. Hyperinflammation and immune response generation in COVID-19. Mishra KP, Singh AK, Singh SB. Neuroimmunomodulation 2020;27(2):80-86

291. Immunosuppression for hyperinflammation in COVID-19: a double-edged sword? Ritchie AI, Singanayagam A. Lancet 2020: 395(10230):1111

292. Immunopathology of Hyperinflammation in COVID-19 Gustine JN, Jones D. Am J Pathol 2021; 191(1):4-17

293. The vascular endothelium: the cornerstone of organ dysfunction in severe SARS-CoV-2 infection. Pons S, Fodil S, Azoulay E, et al. Crit Care 2020;24(1):353

294. Understanding COVID-19: in the end is it endothelium-what else? Lüscher TF. Eur Heart J 2020;41(32):3023-27

295. COVID-19 is, in the end, an endothelial disease. Libby P, Lüscher T. Eur Heart J 2020; 41(32):303844

296. Endothelial dysfunction in COVID-19: lessons learned from coronaviruses. Gavriilaki E, Anyfanti P, Gavriilaki M, et al. Curr Hypertens Rep 2020; 22(9):63

297. Endothelial dysfunction in COVID-19: a position paper of the ESC Working Group for Atherosclerosis and the ESC Council of Basic Cardiovascu- 
lar Science. Evans PC, Rainger GE, Mason JC, et al. Cardiovasc Res 116(14):2177-84

298. Endothelial cells and SARs-CoV-2: an intimate relationship. Barbosa LC, Gonçalves TL, de Araujo LP, et al. Vasc Pharmacol 2021; 137:106829

299. Endothelial dysfunction in COVID-19: current findings and therapeutic implications. Nägele MP, Haubner B, Tanner FC, et al. Atherosclerosis 2020;314:58-62

300. COVID-19 and cardiovascular consequences: is the endothelial dysfunction the hardest challenge? Del Turco S, Vianello A, Ragusa R, et al. Thromb Res 2020;196:143-51

301. COVID-19, the pandemic of the century and its impact on cardiovascular diseases. Zhang Y, Wang M, Zhang X, et al. Cardiol Discov 2021; $1(4): 233-58$

302. Cardiovascular manifestations of COVID-19 infection. Magadum A, Kishore R. Cells 2020;9(11):2508

303. COVID-19 and the cardiovascular: a comprehensive review. Azevedo RB, Botelho BG, Hollanda JVG, et al. J Hum Hypertens 2021; 35(1):4-11

304. Low brachial flow-mediated dilation predicts worse prognosis in hospitalized patients with COVID-19. Bianconi V, Mannarino MR, Figorilli F, et al. J Clin Med 2021; 10(22):5456

305. Immunity, endothelial injury and complement-induced coagulopathy in COVID-19. Perico L, Benigni A, Casiraghi F, et al. Nat Rev Nephrol 2021; 17(1):46-64

306. Endothelial dysfnction and thrombosis in patients with COVID-19: brief report. Nagashima S, Mendes MC, Camargo Martins AP, et al. Atheroscler Thromb Vasc Biol 2020; 40(10):2404-07

307. Endothelial activation and dysfunction in COVID-19: from basic mechanisms to potential therapeutic approaches. Jin Y, Ji W, Yang $\mathrm{H}$, et al. Signal Transduct Target Ther 2020;5(1):293

308. Inflammation resolution: a dual-pronged approach to averting cytokine storms in COVID-19? Panigrahy D, Gilligan MM, Huang S, et al. Cancer
Metastasis Rev 2020;39(2):337-40

309. COVID-19 may predispose to thrombosis by affecting both vascular endothelium and platelets. Cure E, Cure MC. Clin Appl Thromb Hemost 2020; 26:1076029620933945

310. Endothelial dysfunction contributes to COVID-19-associated vascular inflammation and coagulopathy. Zhang J, Tecson KM, McCullough PA. Rev Cardiovasc Med 2020;21(3):315-19

311. The coagulopathy, endotheliopathy, and vasculitis of COVID-19. Iba T, Connors JM, Levy JH. Inflamm Res 2020; 69(12):1181-89

312. COVID-19-associated coagulopathy and disseminated intravascular coagulation. Asakura $\mathrm{H}$, Ogawa H. Int J Hematol 2021;113(1):45-57

313. COVID-19 and ROS storm: what is the forecast for hypertension? de Oliveira AA, Priviero F, Lima VV, et al. Am J Hypertens 2021; 34(8):779-82

314. Elucidating of oxidative distress in COVID-19 and methods of its prevention. Barciszewska AM. Chem Biol Interact 2021; 344:109501

315. What can cellular redox, iron, and reactive oxygen species suggest about the mechanisms and potential therapy of COVID-19. Muhoberac BB. Front Cell Infect Microbiol 2020; 10:569709

316. Oxidative stress as key player in Severe Acute Respiratory Coronavirus (SARS-CoV) infection. Delgado-Roche L, Mesta F. Arch Med Res 2020;51(5):384-87

317. Neurological implications of COVID-19: role of redox imbalance and mitochondrial dysfunction. Kaundal RK, Kalvala AK, Kumar A. Molecular Neurobiol 2021; 58(9):4575-87

318. Reactive oxygen species, proinflammatory and immunosppressive mediators induced in COVID-19: overlapping biology with cancer. Kalyanaraman B. RSC Chem Biol 2021;2(5):1402-14

319. Tissue damage damage from neutrophil-induced oxidative stress in COVID-19. Schönrich G, Raftery MJ, Samstag Y, et al. Nat Rev Immunol 2020; 20(9):515-16 
320. The longitudinal immune response to coronavirus disease 2019: chasing the cytokine storm. Chau AS, Weber AG, Maria NI, et al. Arthritis Rheumatol 2021; 73(1):23-35

321. Clinical features of patients infected with 2019 novel coronavirus in Wuhan, China Huang C, Wang Y, Li X. Lancet 2020 Feb 15;395(10223):497-506.

322. Presenting Characteristics, Comorbidities, and Outcomes Among 5700 Patients Hospitalized With COVID-19 in the New York City Area. Richardson S, Hirsch JS, Narasimham M. JAMA 2020;323(2):2052-59

323. Clinical course and risk factors for mortality of adult inpatients with COVID-19 in Wuhan, China: a retrospective cohort study. Zhou F, Yu T, Du $\mathrm{R}$, et al. Lancet 2020; 395(10229):1054-62

324. Clinical characteristics and survival analysis in critical and non-critical patients with COVID-19 in Wuhan, China: a single-center retrospective case control study. Tian R, Wu W, Wang C, et al. Sci Rep 2020; 10(1):17524

325. Haematological characteristics and survival analysis in the classification and prognosis evaluation of COVID-19: A retrospective cohort study. Liao D, Zhou F, Luo L, et al. 2020; 7(9):e671-78

326. Factors associated with death outcome in patients with severe coronavirus disease-19 (COVID-19): a case-control study. Pan F, Yang L, Li Y. J Med Sci 2020; 17(9):1281-92

327. Clinical characteristics of patients with severe pneumonia caused by SARS-CoV-2 in Wuhan, China. Wang Y, Zhou Y, Yang Z, et al. Respiration 2020; 99(8):649-57

328. COVID-19: consider cytokine storm syndromes and immunosuppression. Mehta P, McAuley DF, Brown M, et al. Lancet 2020; 395(10229):1033-34

329. Clinical predictors of mortality due to COVID-19 based on an analysis of data of 150 patients from Wuhan, China. Ruan Q, Yang K, Wang W, et al. J Intensive Care Med 2020; 46(5):846-48

330. Predictors of COVID-19 severity: a literature review. Gallo Marin B, Aghagoli G, Lavine K, et al.
Rev Med Virol 2021; 31(1):1-10

331. Clinical characteristics and day-90 outcomes of 4244 critically ill adults with COVID-19: A prospective cohort study. COVID-ICU Group on behalf of the REVA Network and the COVID-ICU. Intensive Care Med 2021;47(1):60-73

332. Cytokine storm in COVID-19: pathogenesis and overview of anti-inflammatory agents used in treatment. Soy M, Keser G, Atagündüz P, et al. Clin Rheumatol 2020; 39(7):2085-94

333. Controlling the cytokine storm is vital in COVID-19. Tang L, Yin Z, Hu Y, et al. Front Immunol 2020;11:570993

334. Inflammatory response in COVID-19 patients resulting from the interaction of the inflammasome and SARS-CoV-2. Cheon SY, Koo BN. Int J Mol Sci 2021;22(15):7914

335. Targeting the NLRP3 inflammasome in severe COVID-19. Freeman TL, Swartz TH. Front Immunol 2020;11:1518

336. Inflammation and pyroptosis as therapeutic targets for COVID-19. Yap JKY, Moriyama M, Iwasaki A. J Immunol 2020; 205(2):307-12

337. Controlling the cytokine storm is vital in COVID-19. Tang L, Yin Z, Hu Y, et al. Front Immunol 2020;11:570993

338. The cytokine storm and COVID-19. Hu B, Huang S, Yin L. J Med Virol 2021; 93(1):250-56

339. Cytokine storm in COVID-19: pathogenesis and overview of anti-inflammatory agents used in treatment. Soy M, Keser G, Atagündüz P, et al. Clin Rheumatol 2020; 39(7):2085-94

340. COVID-19: consider cytokine storm syndromes and immunosuppression. Mehta P, McAuley DF, Brown M, et al. Lancet 2020; 395(10229):1033-34

341. Immunopathology of Hyperinflammation in COVID-19 Gustine JN, Jones D. Am J Pathol 2021; 191(1):4-17

342. Hyperinflammation and immune response generation in COVID-19. Mishra KP, Singh AK, Singh SB. Neuroimmunomodulation 2020; 27(2):80-86 
343. Autoantibodies related to systemic autoimmune rheumatic diseases in severely ill patients with COVID-19. Vlachoyiannopoulos PG, Magira E, Alexopoulos H, et al. Ann Rheum Dis 2020; 79: 1661-1663.

344. COVID-19 and autoimmunity. Ehrenfeld M, Tincani A, Andreoli L, et al. Autoimmune Rev 2020; 19(8): 102597

345. Seronegative erosive osteoarthritis following SARS-CoV-2 infection. Drosos AA, Pelechas E, Voulgari PV. Rheumatol Ther 2021; 16:1-7

346. Autoimmune and rheumatic musculoskeletal diseases as a consequence of SARS-CoV-2 infection and its treatment. Shah S, Danda D, Kavadichanda $C$ et al Rheumatol Int 2020; 40(10): 1539-54

347. Concomitant new diagnosis of systemic lupus erythematosus and COVID-19 with possible antiphospholipid syndrome. Just a coincidence? A case report and review of intertwining pathophysiology. Mantovani Cardoso E, Hundal J, et al. Clin Rheumatol 2020; 39(9): 2811-2815

348. Positive anti-SSA/Ro antibody in a woman with SARS-CoV-2 infection using immunophenotyping: a case report. Huang PI, Lin TC, Liu FC, et al. Medicina (Kaunas) 2020; 56(10): 521

349. High levels of anti-SSA/Ro antibodies in COVID-19 patients with severe respiratory failure: a case-based review: high levels of anti-SSA/Ro antibodies in COVID-19. Fujii H, Tsuji T, Yuba T, Tanaka S, et al. Clin Rheumatol 2020; 39(11): 3171-75

350. Diverse functional autoantibodies in patients with COVID-19. Wang EY, Mao T, Klein J, et al. medRxiv 2021; 2020.12.10.20247205

351. Prothrombotic autoantibodies in serum from patients hospitalized with COVID-19. Zuo Y, Estes SK, Ali RA, et al. Sci Transl Med 2020;12(570) eabd3876

352. Autoantibodies against type I IFNs in patients with life-threatening COVID-19. Bastard P, Rosen LB, Zhang Q, et al. Science 2020; 370(6515): eabd 4585
353. Antinuclear antibodies (ANAs) detected by indirect immunofluorescence (IIF) method in acute COVID-19 infection: future roadmap for laboratory diagnosis. Peker BO, Şener AG, Kaptan Aydoğmuş F. J Immunol Methods 2021; 499:113174

354. Apoptosis, pyroptosis, and necrosis: mechanistic description of dead and dying eukaryotic cells. Fink SL, Cookson BT. Infect Immunol 2005; 73)4):1907-16

355. COVID-19 and neutrophils: the relationship between hyperinflammation and neutrophil extracellular traps. Borges L, Pithon-Curi TC, Curi R, et al. 2020; 2020:8829674

356. The emerging role of neutrophils in the pathogenesis of thrombosis in COVID-19. Iliadi V, Konstantinidou I, Aftzoglou K, et al. Int J Mol Sci 2021; 22(10):5368

357. Neutrophil extracellular traps contribute to immunothrombosis in COVID-19 acute respiratory distress syndrome. Middleton EA, He XY, Denorme F, et al. Blood 2020; 136(10):1169-79

358. A NET-thrombosis axis in COVID-19. Hidalgo A. Blood 2020; 136(10):1118-19

359. Neutrophil extracellular traps (NETS) in autoimmune diseases: a comprehensive review. Lee $\mathrm{KH}$, Kronbichler A, Park DD, et al. Autoimmun Rev 2017; 16(11):1160-73

360. The Emerging Role of Neutrophils in the Pathogenesis of Thrombosis in COVID-19. Iliadi V, Konstantinidou I, Aftzoglou K. Int J Mol Sci 2021

361. Neutrophil extracellular traps contribute to COVID-19 Hyperinflammation and humoral autoimmunity. Torres-Ruiz J, Absalón-Aguilar A, Nuñez-Aguirre M, et al. Cells 2021; 10(10):2545

362. Autoantibodies stabilize neutrophil extracellular traps in COVID-19. Zuo Y, Yalavarthi S, Navaz SA, et al. JCI Insight 2021; 6(15):150111

363. Neutrophil extracellular traps (NETs) in severe SARS-CoV-2 lung disease. Szturmowicz M, Demkow U. Int J Mol Sci 2021; 22(16):6854 
364. COVID-19 and neutrophils: the relationship between hyperinflammation and neutrophil extracellular traps. Borges L, Pithon-Curi TC, Curi R, et al. Mediators Inflamm 2020; 2020:8829674

365. The emerging role of neutrophils in the pathogenesis of thrombosis in COVID-19. Iliadi V, Konstantinidou I, Aftzoglou K, et al. Int J Mol Sci 2021; 22(10): 5638

366. Vasculitis and neutrophile extracellular traps in lungs of Golden Syrian hamsters with SARS-CoV-2. Becker K, Beythien G, de Buhr N, et al. Front Immunol 2021; 12: 640842

367. Neutrophil extracellular traps contribute to immunothrombosis in COVID-19 acute respiratory distress syndrome. Middleton EA, He XY, Denorme F, et al. Blood 136(10): 1169-79

368. The immunology of macrophage activation syndrome. Crayne CB, Albeituni S, Nichols KE, et al. Front Immunol 2019; 10:119

369. Macrophage activation syndrome. Ravelli A, Davì S, Minoia F, et al. Hematol Oncol Clin North Am 2015; 29(5):927-41

370. IL-1 induces thromboxane-A2 (TxA2) in COVID-19 causing inflammation and micro-thrombi: inhibitory effect of the IL-1 receptor antagonist (IL-1Ra). Conti P, Caraffa A, Gallenga CE, et al. Biol Regul Homeost Agents 2020;34(5):1623-27

371. COVID-19-associated coagulopathy: an exacerbated immunothrombosis response. Jayarangaiah A, Kariyanna PT, Chen X, et al. Clin Appl Thromb Hemost 2020; 26:1076029620943293

372. Coagulopathy of coronavirus disease 2019. Iba T, Levy JH, Levi M, et al. Crit Care Med 2020; 48(9):1358-64

373. COVID-19-associated coagulopathy: an exploration of mechanisms. Colling ME, Kanthi Y. Vasc Med 2020; 25(5):471-78

374. COVID-19: coagulopathy, risk of thrombosis, and the rationale for anticoagulation. Miesbach W, Makris M. Clin Appl Thromb Hemost 2020; 26:1076029620938149
375. COVID-19-associated coagulopathy and disseminated intravascular coagulation. Asakura H, Ogawa H. Int J Hematol 2021;113(1):45-57

376. Case Fatality Rates for Patients with COVID-19 Requiring Invasive Mechanical Ventilation. A Meta-analysis. Lim ZJ, Subramaniam A, Reddy MP, et al. Am J Resp Crit Care Med 2021; 203(1):54-66

377. Tissue-based SARS-CoV-2 detection in fatal COVID-19 infections: sustained direct viral-induced damage is not necessary to drive disease progression. El Jamal SM, Pujadas E, Ramos I, et al. Hum Pathol 2021;114:110-19

378. Pulmonary pathology of COVID-19: A review of autopsy studies. Borczuk AC. Curr Opin Pulm Med 2021; 27(3):184-92

379. Organ-specific manifestations of COVID-19 infections. Gavriatopoulou M, Korompoki E, Fotiou D, et al. Clin Exp Med 2020; 20(4):493-506

380. Pulmonary pathology of ARDS in COVID-19: a pathological review for clinicians. Batah SS, Fabro AT. Resp Med 2021; 176:106239

381. Severe acute respiratory syndrome coronavirus- 2 (SARS-CoV-2) and coronavirus disease 19 (COVID-19)-anatomic pathology perspective on current knowledge. Mohanty SK, Satapathy A, Naidu MM, et al. Diagn Pathol 2020;15(1):103

382. Cardiovascular complications in COVID-19. Long B, Brady WJ, Koyfman A, et al. Am J Emerg Med 2020; 38(7):1504-07

383. Cardiac and arrhythmic complications in patients with COVID-19. Kochi AN, Tagliari AP, Forleo GB, et al. J Cardiovasc Electrophysiol 2020;31(5):1003-08

384. Myocarditis in COVID-19 patients: current problems. Mele D, Flamigni F, Rapezzi C, et al. Intern Emerg Med 2021;16(5):1123-29

385. Kidney involvement in COVID-19 and its treatments. Han X, Ye Q. J Med Virol 2021;93(3):138795

386. Assessment and characterization of post-COVID-19 manifestations. Kamal M, Abo Omi- 
rah M, Hussein A, et al. Int J Clin Pract 2021; 75(3):e13746

387. Management of acute kidney injury in patients with COVID-19. Kamal M, Abo Omirah M, Hussein A. Lancet Resp Med 2020;8(7):738-42

388. Stroke in patients with COVID-19: clinical and neuroimaging characteristics. Vogrig A, Gigli GL, Bnà C, et al. Neurosci Lett 2021; 743:135564

389. Mechanisms of stroke in COVID-19. Spence JD, de Freitas GR, Pettigrew LC, et al. Cerebrovasc Dis 2020; 49(4):451-58

390. Stroke as a complication and prognostic factor of COVID-19. Trejo-Gabriel-Galán JM. Neurologia (Engl Ed) 2020;35(5):318-22

391. Large-vessel stroke as a presenting feature of COVID-19 in the young. Oxley TJ, Mocco J, Majidi S, et al. NEJM 2020;382(20):e60
392. Postmortem examination of COVID-19 patients reveals diffuse alveolar damage with severe capillary congestion and variegated findings in lungs and other organs suggesting vascular dysfunction. Menter T, Haslbauer JD, Nienhold R, et al. Histopathology 2020; 77(2):198-209

393. Pathophysiology, transmission, diagnosis, and treatment of coronavirus disease 2019 (COVID-19): A review. Wiersinga WJ, Rhodes $\mathrm{A}$, Cheng AC, et al. JAMA 324(8):782-93

394. Influenza: The Last Great Plague. W.I.B. Beveridge publ. Prodist 1978 (p 38)

395. Genes, Dreams and Realities. Macfarlane Burnet publ. Basic Books, Inc., 1971 rectal Cancer A Randomized Clinical Trial. JAMA Intern Med. 2016 Jul 1; 176(7):894-902. 